University of Florida Levin College of Law

UF Law Scholarship Repository

\title{
Discordant Environmental Laws: Using Statutory Flexibility and Multi-Objective Optimization to Reconcile Conflicting Laws
}

Mary Jane Angelo

University of Florida Levin College of Law, angelo@law.ufl.edu

Follow this and additional works at: https://scholarship.law.ufl.edu/facultypub

Part of the Conflict of Laws Commons, and the Environmental Law Commons

\section{Recommended Citation}

Mary Jane Angelo, Discordant Environmental Laws: Using Statutory Flexibility and Multi-Objective Optimization to Reconcile Conflicting Laws, 38 Stan. Envtl. L. J. 165 (2019)

This Article is brought to you for free and open access by the Faculty Scholarship at UF Law Scholarship Repository. It has been accepted for inclusion in UF Law Faculty Publications by an authorized administrator of UF Law Scholarship Repository. For more information, please contact kaleita@law.ufl.edu. 


\title{
Discordant Environmental Laws: Using Statutory Flexibility and Multi-Objective Optimization to Reconcile Conflicting Laws
}

\author{
Mary Jane Angelo*
}

The current morass of federal environmental laws has led to significant conflicts among statutes and the manner in which agencies implement them. In recent years, this quagmire of environmental laws has hindered the progress of a number of high-profile environmental regulatory programs and restoration projects. Neither the Courts nor legal scholars have developed approaches to resolving conflicts in a manner that harmonizes environmental statutes while at the same time protecting the most critical environmental resources. A standard methodology that optimizes the multiple objectives of environmental statutes and their implementing programs would greatly enhance decision-making and ensure that the most salient environmental objectives are met. Multi-objective optimization is a decision-making methodology that seeks to optimize multiple objectives. Although this methodology has been used widely in the business world and in scientific decision-making, it has not yet made its way into the legal discourse. This article suggests multi-objective optimization as a structured decision support tool for prioritizing environmental objectives and reconciling regulatory programs.

\footnotetext{
* Samuel T. Dell Professor and Director, Environmental and Land Use Law Program, University of Florida Frederic G. Levin College of Law. The author thanks the participants of the Southern Environmental Law Scholars Conference co-sponsored by the University of Florida through the Leonhardt Foundation, the University of North Carolina, the University of South Carolina, and Vanderbilt University; David Adelman, Travis Brandon, Blake Hudson, Christine Klein, Amanda Leiter, Jonas Monast, Nathan Richardson, J.B. Ruhl, and Shelly Welton for providing a wonderful exchange of ideas and helpful comments; Gregory Kiker for providing important background information; her colleague Michacl Allan Wolf for proving valuable insights; and Caroline Gibble for outstanding research assistance.
} 


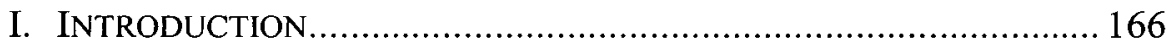

II. Discordant EnVIROMENTAL Statutes: ReAl WORLD

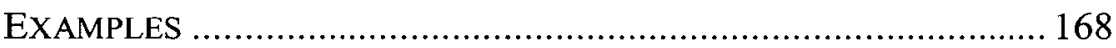

A. One Agency/One Statute: Forest Management Plans ........... 176

B. Two Agencies/Multiple Statutes........................................... 177

1. Renewable Energy and Species Protection ................... 177

2. Pesticide Regulation and Species Protection.................. 179

C. Mulitple Conflicting Statutes: The Everglades Example ...... 185

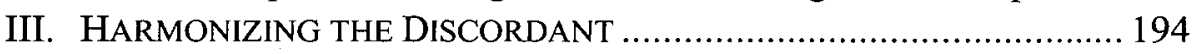

A. Resolution of Conflict in the Courts ................................... 194

B. Multi-objective Optimization ............................................. 199

1. The Basic mechanics of Multi-objective

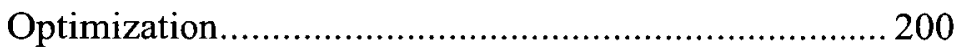

2. The Role Multi-objective Optimization Can Play in Environmental Decision-making................................... 204

IV. Using Multi-OBJECTIVE Optimization: A Fictional

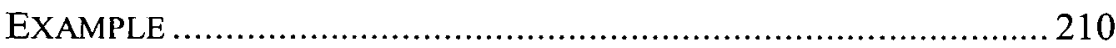

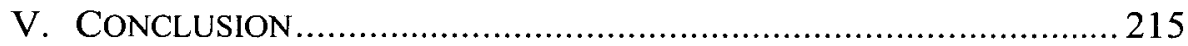

\section{INTRODUCTION}

The sheer volume and complexity of federal laws create multiple, sometimes conflicting, objectives that must be reconciled through administrative policy choices or court decisions. Nowhere is the tension between discordant laws more evident than in environmental law. Although federal environmental laws all seek to protect aspects of the environment, in some circumstances federal environmental statutes come into direct conflict. Such conflicts raise legal issues including: does or should one statute trump another; are the environmental objectives of one statute of higher value than those of another; what statutory or regulatory mechanisms are in place to provide for the flexibility needed to reconcile the objectives or requirements of the conflicting statutes; and when environmental objectives are in conflict how should decision-makers prioritize them?

Rigid statutory schemes and judicial mandates can result in unintended environmental resource tradeoffs. Even where statutes provide flexibility mechanisms for resolving conflicts, challenges remain. Without a structured process for determining how best to resolve conflicts, statutes may be implemented in ways that give priority to less important environmental objectives over more critical ones. In some 
situations, a race to the courthouse may determine which objectives are given priority rather than a reasoned approach to determining how to optimize the most important objectives.

This paper explores potential tools for resolving the types of conflicts that have arisen in a number of real-world circumstances. This article suggests multi-objective optimization as a structured decision support tool to reconcile discordant environmental statutes. The multi-objective approach optimizes the statutes' goals and provides a structured framework for prioritizing objectives and making tradeoffs to achieve the best results possible. Although explored in business, engineering, and environmental management literature for years, multi-objective optimization has yet to become part of the legal scholarly discourse. Not only does this article make the case that multi-objective optimization has the potential to vastly improve environmental decision-making, but it does so within a specific legal context-where environmental laws have conflicting or competing objectives or standards, or where environmental regulatory agencies and courts have interpreted environmental laws in a discordant manner. This article posits that multi-objective optimization can provide a useful roadmap for working through complex environmental law matters and can help to de-conflict discordant environmental laws. Drawing upon real-world conflicts that have arisen in the context of environmental regulation and environmental restoration, this article explores the utility of multi-objective optimization in deconflicting environmental statutes and, through the use of a simplified fictional ecosystem restoration scenario, provides a roadmap for how multi-objective optimization could be used in a qualitative, if not quantitative manner.

Part II of this Article describes the problem of discordant environmental laws and provides several real-world examples. These range from multiple objectives embedded in a single statute administered by a single agency to the morass of competing objectives of various environmental statutes administered by multiple agencies that govern major environmental restoration projects such as the Everglades restoration. The examples set forth in this part illustrate how discordant environmental statutes cause confusion, agency paralysis, and litigation that often create barriers to meeting important environmental objectives. Part III explores how some courts have grappled with resolving discordance among environmental statutes. Part IV of this article describes multi-objective optimization and how it has been employed as a form of multi-criteria decision-making. In Part V, the use of multi- 
objective optimization is demonstrated with a fictional factual scenario involving three federal environmental statutes: the Clean Water Act (CWA), ${ }^{1}$ the Endangered Species Act (ESA), ${ }^{2}$ and the Migratory Bird Treaty Act (MBTA). ${ }^{3}$ This Part explores multi-objective optimization's utility as a means of optimizing environmental statutory objectives where conflicts cannot be avoided. Based on the results of these evaluations, this paper concludes with recommendations for resolving conflicts and optimizing multiple objectives.

\section{Discordant ENVIROMENTAL STATUTES: ReAL WorLd EXAMPLES}

A long-standing challenge in environmental protection, management, and restoration is how to navigate the labyrinth of piecemeal environmental laws, which leaves gaps, overlap, and sometimes conflict, in a manner to address complex ecosystems' needs. ${ }^{4}$ In many circumstances, a variety of federal laws can be used in a complementary way to achieve environmental goals. For example, Sandra Zellmer has opined that while no one federal statute or legal principle can adequately accomplish the task of protecting the wild, the complementary implementation of several laws including the Wilderness Act, the legal doctrines of federally reserved water rights, the Wild and Scenic Rivers Act, and the CWA can better achieve the goal of protection of the wild. ${ }^{5}$ In certain situations, however, laws designed to protect certain aspects of the environment conflict in ways that make it difficult, if not impossible, for agencies to move forward to achieve environmental goals without running afoul of the law. The threat of being sued for violations of

1. 33 U.S.C.S. $\S 1251-1387$ (2012).

2. 16 U.S.C.S. $\$ \S 1531-1544$ (2012).

3. 16 U.S.C.S. $\$ \$ 703-712$ (2012).

4. The examples described in this section involve discordanec between federal environmental statutes. Of course, conflict can occur between state or local government environmental laws. One example of a conflict between local government environmental laws is the conflict between ordinances that require trees to be cut down or trimmed so that the sun can reach solar panels versus tree protection ordinances that prohibit cutting down or trimming of certain trees. A multi-objective optimization strategy may be beneficial in resolving disputes at that level, as well as at the federal level. The multi-objective optimization methodology described in this article would only apply to conflicts between laws at the same level of government. Conflicts between laws at different levels of government invoke other legal solutions. For example, a state environmental protection law that is in direct conflict with a federal environmental protection law may be determined to be impliedly preempted by the federal law. Similar preemption may occur where local government law conflicts with state law.

5. Sandra Zellmer, Wilderness, Water, and Climate Change, 42 Envt'l L. 313, 315 (2012). 
environmental law, whether real or perceived, has at times resulted in regulatory paralysis. The paralysis resulting from an agency's reluctance to act under one environmental law for fear of violation of another can result in delay in environmental protection and in some cases can lead to further environmental degradation. ${ }^{6}$ In most circumstances, conflicts that arise among federal statutes are due to conflicts in the manner in which statutes are interpreted and implemented rather than direct irreconcilable conflicts between the laws. Even where conflicts appear to be insurmountable, however, most environmental statutes contain at least some level of flexibility.

Although conflicts between laws designed to protect environmental values have arisen in a variety of scenarios, the federal environmental statute that appears to conflict the most with other environmental statutes is the U.S. Endangered Species Act (ESA). The ESA is the federal statute targeted at protecting threatened and endangered species and the habitats upon which they rely. The ESA applies to actions carried out by all federal agencies regardless of the agency's statutory mandates or objectives. Accordingly, the ESA's objective of protecting endangered species frequently conflicts with other statutory objectives, such as constructing infrastructure, regulating to protect other resources, or carrying out environmental restoration projects. The interplay between the ESA and other federal environmental laws has not been fully reconciled by Congress, the Courts, or the environmental agencies.

The ESA has been characterized in both the legal literature and court opinions as a particularly rigid and absolutist statute. In particular, the Section 7 consultation requirement is considered to be a legal hammer that can create barriers to a more integrated approach to resolving environmental problems with multiple objectives. The ESA is intended to err on the side of protection of species. Despite its notoriety as perhaps the most hardline environmental law, however, the ESA contains a number of tools that may provide flexibility to resolve some of these conflicts. These include safe harbor agreements, ${ }^{7}$ habitat conservation

6. Nat'L Research Council, Progress toward Restoring the Everglades: The FOURTH BIENNIAL REVIEW.32-37 (2012) [hercinafter NRC Report 2012].

7. Announcement of Final Safe Harbor Policy, 64 Fed. Reg. 32717 (June 17, 1999). 
planning, ${ }^{8}$ water or wildlife mitigation, assisted migration, and incidental take authorizations. ${ }^{9}$

The ESA is administered and enforced by the U.S. Fish and Wildlife Service (FWS) (managing freshwater and terrestrial species) and the National Marine Fisheries Service (NMFS) (managing marine and anadromous species). These two agencies are referred to collectively as "the Services." The two primary protections afforded to species listed pursuant to the ESA are the prohibition on the "taking" of listed species under Section 9 and the consultation requirements under Section 7. The ESA defines the term "take" broadly to include "harass, harm, pursue, hunt, shoot, wound, kill, trap, capture, or collect or attempt to engage in any such conduct." 10 The Services' regulations further define the term "harm" to include acts that involve significant habitat modification or degradation that actually kills or injures wildlife by significantly impairing essential behavior patterns, including breeding, feeding, or sheltering. This regulatory definition has been upheld by the U.S. Supreme Court." Moreover, for habitats designated as "critical habitat[s]," additional protections are afforded. ${ }^{12}$ Violators of the Section 9 take prohibition are subject to injunctive relief and criminal and civil penalties resulting from enforcement actions brought by the Services or legal actions brought by private individuals or organizations pursuant to the ESA's citizen suit provision. ${ }^{13}$

Section 7(a)(2) of the ESA requires that, prior to engaging in any federal agency action that "may affect" listed species, the federal agency must consult with the Services to "insure that any action authorized, funded, or carried out by such agency is not likely to jeopardize the continued existence of any endangered species or threatened species or result in the destruction or adverse modification of [critical habitat] of

8. Habitat Conservation Plan Assurances ("No Surprises") Rule, 63 Fed. Reg. 8859 (February 23, 1998).

9. Endagered Species Act $\S 7(b)(4), 16$ U.S.C.S. § 1536(b)(4) (providing for takes incidental to federal agency action); 16 U.S.C.S. $\$ 1539$ (a) (providing for permit authorization for certain takes that are incidental to non-federal action).

10. Id. $\S 1532(19)$.

11. Babbit v. Swcet Homc Chapter of Cmtys. for a Great Or., 515 U.S. 687 (1995) (upholding as reasonable the Serviccs' definition of harm to include "significant habitat modification or degradation where it actually kills or injures wildlife").

12. Interagency Cooperation - Endangered Species Act of 1973, as Amended; Definition of Destruction of Adverse Modification of Critical Habitat, 81 Fed. Reg. 7214 (February 11, 2016).

13. 16 U.S.C.S. $\$ 1540(2012)$. 
such species." 14 The term "jeopardize the continued existence of a listed species" includes actions that can reasonably be expected, directly or indirectly, to appreciably reduce the likelihood of both the survival and recovery of a listed species in the wild. Through the consultation process, the Services determine whether the federal agency action is likely to jeopardize the continued existence of listed species. Consultation culminates in the Services issuing a Biological Opinion (BiOp). If the Services make a jeopardy finding, the BiOp must include "reasonable and prudent alternatives" that if implemented would avoid jeopardy.

Where an agency determines, with written concurrence of the Services, that its proposed action is "not likely to adversely affect" listed species, a more truncated consultation process known as informal consultation is permitted. Conflicts between the objectives of the ESA and objectives of other environmental statutes frequently arise where a federal agency triggers the need for the consultation or causes a take of a listed species, either by carrying out, funding, or authorizing an activity under the terms of the other environmental statutes.

An example of the perceived rigidity of the ESA is the conflicting objectives of protecting fish species listed under the ESA while providing water necessary for agricultural irrigation. This conflict has existed for quite some time and for many years appeared to be intractable. Many blamed the ESA's perceived rigidity as creating a barrier to addressing system-wide needs in a more integrative manner.

Even the ESA, often considered to be the most inflexible, contains several provisions that allow takes of listed species in certain circumstances. For example, as part of a BiOp for a federal action that may affect a listed species, the Services may issue an incidental take statement, which provides legal cover for limited, specified takes of listed species incidental to the proposed federal action. In many cases, the assurance that limited takes will not result in violations of the ESA or trigger citizen suit enforcement actions may be sufficient to provide the flexibility needed to undertake a federal environmental restoration project, promulgate an environmental regulation, or otherwise exercise authority under a federal environmental statute. Similarly, Section 10 of the ESA authorizes the Services to issue permits to authorize specific "takes" of a listed species, if the "taking is incidental to, and not the purpose of, the carrying out of an otherwise lawful activity" and "will not appreciably reduce the likelihood of the survival and recovery of the

14. Id. $\S 1536(\mathrm{a})(2)$. 
species in the wild." 15 To obtain such a permit, a permit applicant must develop a "habitat conservation plan" that minimizes and mitigates impact of the taking to the maximum extent practicable. ${ }^{16}$ Permittees are shielded from liability provided that they comply with the Reasonable and Prudent Measures contained in the permit and the measures provided in the habitat conservation plan. Additional flexibility is provided by the Services' "Safe Harbor Policy." Pursuant to this policy, the Services will enter into voluntary agreements with private or other non-federal property owners who undertake actions that contribute to the recovery of listed species. In exchange, the property owner receives assurance from the Services that if they comply with the terms of the agreement, the Services will not require any additional or different activities to protect listed species. ${ }^{17}$ Finally, flexibility is provided via the Services' Mitigation Policy, which authorizes the Services to require compensatory mitigation for impacts to listed species for federal actions that require an incidental take statement under Section 7 and for incidental take permits issued under Section $10 .{ }^{18}$ These flexibility mechanisms alleviate much of the ESA's rigidity.

In fact, there are several instances where federal agencies have used flexibility in the ESA to address socioeconomic concerns while still ensuring species protection have succeeded. For example, Gosnell et al., explain how an integrative systems-based approach to resolving conflicts between fish protection under the ESA and agricultural interests in the Klamath basin resulted in a 2013 joint BiOp containing coordinated, place-based recommendations for conserving species while meeting the needs of agricultural interests. ${ }^{19}$ The authors suggest that by identifying leaders who can find ways to creatively avoid entrenchment and facilitate

15. Id. $\S 1539(\mathrm{a})$.

16. Habitat Conscrvation Plan Assurances ("No Surprises") Rule, 63 Fed. Reg. 8859 (Fcbruary 23, 1998). See also John Charles Kunich, Species and Habitation Conservation: The Fallacy of Deathbed Conservation under the Endangered Species Act, 24 ENVTL. L. 501 (1994); Karin P. Sheldon, Habitat Conservation Planning: Addressing the Achilles Heel of the Endangered Species Act, 6 N.Y.U. ENVTL. L.J. 279 (1998); Robcrt D. Thornton, The Endangered Species Act: Searching for Consensus and Predictability: Habitat Conservation Planning Under the Endangered Species Act of 1973, 21 ENVTL. L. 605 (1991).

17. Announcement of Final Safe Harbor Policy, 64 Fed. Reg. 32717 (June 17, 1999); Habitat Conservation Plan Assurances ("No Surprises") Rule, 63 Fed. Reg. 8859 (February 23, 1998).

18. U.S. Fish and Wildlife Service Mitigation Policy, 81 Fed. Reg. 83440 (Nov. 21, 2016).

19. See Hannah Gosnell et al., Transforming (Perceived) Rigidity in Environmental Law Through Adaptive Governance: A Case of Endangered Species Act Implementation, 22 ECOLOGY \& SOC'Y 42 (2017). 
cooperation in the early stages of problem solving, more cooperative and adaptive resolution of environmental problems can be found.

Examples of creative, cooperative, and integrative approaches to resolving environmental problems demonstrate that statutory rigidity is often more perceived than real, and communication, cooperation, and trust can go a long way to find solutions that meet multiple objectives even in the face of the rigid mandates of the ESA. ${ }^{20}$ Nevertheless, even where creativity can be employed in a way to reduce rigidity and provide flexibility, it is still necessary to have a process in place to guide optimization of multiple objectives such that flexible approaches are used in an optimal manner.

Frequently, but not always, conflicts involving the ESA also involve other wildlife protection statutes such as the Migratory Bird Treaty Act (MBTA). ${ }^{21}$ As with the ESA, the MBTA can be triggered when the use of pesticides harms covered species. The MBTA implements four international treaties that are aimed at protecting migratory birds. The scope of the MBTA is quite broad and covers almost all native North American birds. ${ }^{22}$ Some, but not all, migratory birds covered by the MBTA are also a listed species under the ESA and thus both Acts apply to those species. Under the MBTA, it is unlawful at any time, by any means or in any manner to: hunt, take, capture, kill, possess, purchase, sell, barter, or transport any bird protected by the Treaty, any part, nest, or egg of a protected bird or any product composed of any part, nest, or egg of a protected bird, except as permitted by regulation of the Secretary of the Interior. ${ }^{23}$ Violations of this prohibition can result in criminal penalties. ${ }^{24}$ As with the ESA, the MBTA prohibits "takes," however, the MBTA does not define the term. Regulations adopted pursuant to the MBTA define "take" to mean "pursue, hunt, shoot, wound, kill, trap, capture, or collect, or attempt" any of the foregoing. ${ }^{25}$ In contrast to the ESA, the regulatory definition of harm under the MBTA does not

20. $I d$.

21. 16 U.S.C.S. $\$ \S 703-712$ (2012). For the protection of marine mammals, the primary legislative authority is the Marine Mammal Protection Act. 16 U.S.C.S. $\S \S 1361-1421$ (2012).

22. Larry Martin Corcoran \& Elinor Colbourn, Shocked, Crushed and Poisoned: Criminal Enforcement in Non-Hunting Cases Under the Migratory Bird Treaties, 77 DENV. U. L. REV. 359 , 378 (1999). However, non-native species are not covered, and hence not protected, under the MBTA. Id. at 381-85.

23. 16 U.S.C.S. $\S 703(2012)$.

24. $I d . \S 707(2012)$.

25. 50 C.F.R. $\S 10.12(2018)$. 
expressly include habitat modifications and the courts have not definitely weighed in on how far the MBTA goes to protect habitat. ${ }^{26}$

Unlike the ESA, the MBTA does not expressly contemplate authorization of incidental takes of protected species and to date, the USFWS has not promulgated a regulatory program to do so. In May 2015, USFWS issued a Notice expressing its planned proposal to authorize incidental take of migratory birds under the MBTA. The USFWS indicated that it was considering a variety of approaches, including general authorization for certain types of hazards to birds associated with particular industry sectors. It also indicated it was contemplating creating memoranda of understanding with federal agencies authorizing incidental take from those agencies' "operations and activities" to encourage agencies to employ appropriate conservation measures to avoid or reduce avian mortality and to create a regulatory mechanism for mortality that cannot be avoided or minimized through best practices or technologies. To date, the USFWS has not published the proposed rule. Nevertheless, in the past, USFWS has permitted limited "takes" of birds under specific circumstances through the issuance of "special use" permits for incidental takes under limited specified circumstances ${ }^{27}$ pursuant to an existing rule that authorizes the issuance of permits for special purpose activities if there is a benefit to the migratory bird resource or for other compelling reasons. USFWS has relied on this rule to authorize incidental takes of avian species protected by the MBTA, including permitting the National Marine Fisheries Service to take birds incidental to certain fishing operations in Hawaii. ${ }^{28}$ In the past, USFWS has entered into memoranda of understanding with federal agencies, including with the Federal Energy Regulatory Commission, recognizing that "actions taken to benefit some migratory bird populations may adversely affect other migratory bird

26. See Corcoran \& Colbourn, supra note 22, at 390.; Conrad A. Fjetland, Possibilities for Expansion of the Migratory Bird Treaty Act for the Protection of Migratory Birds, 40 NAT. RES. J. 47, 50-54 (2000) (tracing the history of MBTA cases where parties were found liable for indirect takings of migratory birds, including takings that occurred as a result of pesticide poisoning); Erin C. Perkins, Migratory Birds and Multiple-Use Management: Using the Migratory Bird Treaty Act to Rejuvenate America's National Environmental Policy, 92 NW. U. L. REV. 817 (1998).

27. NAT'L ACAD. OF SCI., ENGINEERING, \& MED., Progress TOWARD Restoring the EVERGLADES: THE SIXTH BIENNIAL REVIEW 65 (2016) [hereinafter NRC Report 2016]; 50 C.F.R. $\S 21.27(2018)$.

28. U.S. Fish \& WiLdLIFE SERVICE, DRAFT ENVIRONMENTAL ASSESSMENT: ISSUANCE OF AN MBTA PERMIT TO THE NATIONAL MARINE FISHERIES SERVICE AUTHORIZING INCIDENTAL TAKE OF SEABIRDS IN THE HAWAII-BASED SHALLOW-SET LONGLINE FISHERY (2012), hitps:// www.fws.gov/pacific/migratorybirds/pdf/NMFS\%20Permit\%20Draft\%20EA.pdf. 
populations" and that "actions that may provide long-term benefits to migratory bird populations may have short-term impacts on individual birds." 29

The problem of optimizing multiple objectives becomes more complex when dealing with two or more environmental statutes implemented by more than one environmental agency. Although statutes such as the ESA and the MBTA may have differing objectives than some other environmental statutes, in many cases, it is not the statutes themselves that are the primary problems. Instead, agency regulations and policies implemented under the statutes may be the primary sources of the discordancy. Under the Chevron doctrine, courts will afford deference to each agency in the way it interprets the statute it is charged with implementing. ${ }^{30}$ If agencies interpret their respective statues in ways that conflict, conflicts will arise that may be difficult to for courts to reconcile. One agency's regulatory choice may conflict with the manner in which another agency implements its regulatory programs. For example, the text of the ESA provides very limited instruction on the process by which agencies must consult under Section $7 .{ }^{31}$ Instead, the processes that agencies must undergo have been spelled out in detail through regulations promulgated by the Services. ${ }^{32}$ The Services' consultation process can be time and resource-intensive and can cause delay and challenges for agencies, such as EPA, in implementing their own regulations and programs aimed at other aspects of environmental protection. Moreover, historical agency processes and cultures may exacerbate conflicts and serve as barriers to resolution. Historical agency processes and differences in institutional culture were part of the source of conflict between the ESA and the Federal Insecticide, Fungicide and Rodenticides Act (FIFRA), described below. ${ }^{33}$ When evaluating discordant statues, it is important to

29. Memorandum of Understanding Between the Federal ENERgy Regulatory COMMISSION AND THE U.S. DEPARTMENT OF THE INTERIOR UNITED STATES FISH AND WILDLIFE SERVICE REGARDING IMPLEMENTATION OF EXECUTIVE ORDER 13186, "RESPONSIBILITIES OF FEDERAL AGENCIES TO PROTECT MIGRATORY BIRDS" (2011), https://www.ferc.gov/legal/mou/ mou-fws.pdf (last visited August 12, 2018).

30. Chevron, U.S.A., Inc. v. NRDC, Inc., 467 U.S. 837 (1984) (establishing a two-part test for judicial review of agency action and holding that where Congress has not directly spoken to an issue or where a statue is ambiguous, courts are to give deference to permissible agency interpretations of the statute).

31. See 16 U.S.C.S. $\$ 1536(2012)$.

32. See 40 C.F.R. $\S 93.105$ (b) (2012).

33. NAT'L RESEARCH COUNCIL, ASSESSING RISKS TO ENDANGERED AND THREATENED SPECIES FROM PESTICIDES 4 (2013) [hereinafter FIFRA/ESA NRC Report]. 
consider whether the root of the problem is statutory, regulatory, or agency culture. Inertia and reluctance to deviate from the status quo may be barriers to overcoming agency culture. From a legal standpoint, it will be easier to modify the culture than to persuade Congress to amend statutes in ways that better reconcile their objectives or even to convince agencies to undertake the arduous rulemaking process to harmonize environmental objectivès and processes.

\section{A. One Agency/One Statute: Forest Management Plans}

National Forests are managed by the U.S. Forest Service pursuant to the requirements of the National Forest Management Act (NFMA) ${ }^{34}$ Although management of National Forests is governed by a single agency under a single statute, the statute mandates that the Forest Service engage in National Forest System Resource Planning to provide for multiple uses and sustained yields of forest products. ${ }^{35}$ The Forest Service regulations promulgated pursuant to the Act set forth a lengthy list of ecological and socioeconomic concerns that must be included in each plan, including: air quality; water quality; cultural and historic resources; ecosystem service; opportunities for timber and forage production; opportunities to connect people with nature; restoring and protecting riparian areas; reduction of soil erosion and sedimentation; and sustainable recreation. ${ }^{36}$ Certain of these objectives may conflict with each other. For example, actions designed to protect ecosystem services may be inconsistent with promoting forage opportunities by limiting the acreage that can be harvested. Similarly, managing in a way to protect water quality by minimizing pollution runoff may reduce timber production by requiring harvesting to be done in a more deliberate manner rather than through traditional clearcutting. Accordingly, the Forest Service, in developing a Forest Management Plan, must find ways to balance and harmonize competing objectives. Because the Forest Service is a single agency operating under a single statute and because considerable flexibility is built into the governing statute and regulations-i.e., there is not an absolute requirement to achieve each objective in every area of each National Forest-attempts to harmonize discordancy within a Forest Management Plan do not encounter the same hurdles as those faced by

34. National Forest Management Act of 1976, 16 U.S.C.S. $\S ~ 1600-1614$ (2012).

35. Id. $\S 1604$.

36. 36 C.F.R. $\S \S 219.8-10$ (2018). 
multiple agencies operating under multiple statutes with more rigid requirements.

\section{B. Two Agencies/Multiple Statutes}

The challenges posed by discordant environmental laws become more profound where more than one agency is involved and multiple statutes are at play. In such circumstances, differences in agency culture, combined with conflicting statutory mandates, objectives, and standards, have resulted in decision-making paralysis and absurd outcomes at odds with environmental protection goals.

\section{Renewable energy and species protection}

One area where the objectives of both the ESA and the MBTA conflict with environmental objectives of other environmental laws involves the use of renewable energy sources to mitigate climate change contributing greenhouse gas emissions, which has led to an increase in wind energy production. ${ }^{37}$ The most significant rule in this regard is the Obama Administration's Clean Power Plan regulation, promulgated pursuant to the Clean Air Act and later proposed to be dismantled by the Trump Administration. ${ }^{38}$ This regulation would have established, among other things, zero emission renewable energy such as wind power as a means of meeting the emissions reductions required under the regulation. ${ }^{39}$

While there is little doubt that wind production has significant environmental benefits in reducing greenhouse gas (GHG) emissions,

37. See Samuel J. Panarella, For the Birds: Wind Energy, Dead Eagles, and Unwelcome Surprises, 20 HASTINGS W.-Nw. J. ENVTL. L. \& POL'Y 3 (2014); Derek Bertsch, When Good Intentions Collide: Seeking a Solution to Disputes Between Alternative Energy Development and the Endangered Species Act, 14 SuSTAINABLE DEV. L.J. 74 (2011).

38. Standards of Performance for Greenhouse Gas Emissions from New, Modified, and Reconstructed Stationary Sources: Electric Utility Generating Units, 80 Fed. Reg. 64510 (October 23, 2015).

39. The Clean Power plan was challenged in Court and the Supreme Court stayed its implementation. Shortly after taking office, President Trump, through executive order, called for the review of the Clean Power Plan. Exec. Order No. 13,783, 82 Fed. Reg. 16093 (Mar. 28, 2017). The Trump administration has since announced that it plans to replace the Clean Power plan with an alternative regulation but has not yet disclosed the requirements of the replacement regulation. See Timothy Cama, Trump Officials Eying Replacement for Key Obama Climate Rule, THE HILL (Sept. 15, 2017), http://hehill.com/policy/energy-environment/350759-trump-officials-eyingreplacement-for-key-obama-climate-rule. On August 21, 2018, EPA proposed the "Affordable Clcan Encrgy Rulc," which is designed to be a substitute for the Clean Power Plan. See Envtl. Prot. Agency, Proposal: Affordable Clean Energy (ACE) Rule (Aug. 21, 2018), https:/www.epa.gov/ stationary-sources-air-pollution/proposal-affordable-clean-energy-acc-rulc. 
there is also a downside. Studies demonstrate that wind turbines harm avian and bat species, many of which are protected by the ESA or MBTA, through direct collisions, electrocution, and affecting behaviors such as foraging and migrations. ${ }^{40}$ Thus, the statutes' multiple objectives-which include reducing GHG emissions to mitigate climate change, protecting endangered species, and protecting migratory birds - create a classic multi-objective problem. The problem is compounded, moreover, by the fact that three different environmental laws clash in a way that makes it difficult to comply with all three.

The environmental decision-making problem created by pitting wind production against birds and bats is more complex than it may seem at first blush. Wind energy is an important component of renewable energy necessary to achieve a reduced-carbon society. ${ }^{41}$ Widespread use of renewable energies has the potential to mitigate climate change. ${ }^{42}$ Significant climate change mitigation will have worldwide environmental benefits, including the benefit of protecting countless species from the risk of potential extinction. ${ }^{43} \mathrm{~A}$ number of options could be employed to optimize one or the other objective. For example, locations such as migratory bird flyways might be classified as inappropriate locations for wind turbines. Moreover, there may be ways to construct or operate wind turbines that reduce the risk of bird collisions.

On the other hand, some avian or bird mortality may be acceptable, given the significant benefits of renewable energy. ${ }^{44}$ Perhaps some species, such as non-native species or species that exist in great abundance, may be more expendable than others, such as threatened or endangered species or species that play important roles in ecosystem function. ${ }^{45}$ A range of potential options may exist, each of which comprises a trade-off between the objectives of maximizing renewable energy production and protecting avian species. Decision-makers must choose from among these options, none of which are ideal for both objectives. Nevertheless, it is possible to find ways to harmonize these

40. Bertsch, supra note 37, at 81-82.

41. Michacl B. Gerrard, Legal Pathways for a Massive Increase in Utility-Scale Renewable Generation Capacity, 47 ENVTL. L. REP. NEWS \& ANALYSIS 10591 (2017).

42. Id.

43. James Ming Chen, Protecting Biodiversity Against the Effects of Climate Change Through the Endangered Species Act, 47 WASH. U. J.L. \& POL'Y 11 (2015).

44. See Cassie Tigue, Wind Energy Development and Protection of Wildlife: Creating a Balance Between Two Competing Interests, 45 TEX. ENVTL. L.J. 223 (2015).

45. See id. 
discordances through regulatory processes without requiring statutory amendment.

\section{Pesticide regulation and species protection}

The ESA also conflicts in a number of significant ways with the Federal Insecticide, Fungicide, and Rodenticide Act (FIFRA). The two statutes differ dramatically in their goals, standards, focus, and method. These conflicts have created a decades-long stand-off between the U.S. Environmental Protection Agency (EPA), the agency charged with implementing FIFRA, and the Services, the federal agencies charged with ESA implementation and enforcement. In a previous article, the author addressed the challenge of reconciling FIFRA's cost-benefit balancing standard for regulatory decision-making regarding pesticides, with the ESA's absolutist prohibitions on takes of listed species and prevention of jeopardy to listed species. ${ }^{46}$ EPA and the Services spent years at odds over these differing approaches, as well as the differing geographic and temporal focus and differing risk reduction methods under the two statutes. ${ }^{47}$

One of the most significant conflicts between the ESA and FIFRA is the disparate standards that govern regulatory action under the respective statutes. ${ }^{48}$ EPA's interpretation and implementation of FIFRA involves a balancing of the risks associated with the use of the pesticide against the social and economic benefits to society accruing from the use of the pesticide. Accordingly, the potential exists for a pesticide that poses high risks to threatened or endangered species to be registered under FIFRA, if that pesticide provides economic benefits that outweigh those risks. ${ }^{49}$ Conversely, the ESA strictly prohibits takes of threatened and endangered species without consideration of economic or other social concerns. The Section 7 consultation mandates ensure that federal agency actions do not jeopardize the continued existence of a threatened and endangered species. ${ }^{50}$ Accordingly, the very terms of the statutes have created a catch22 situation for EPA. If EPA follows the FIFRA cost-benefit standard, it may approve a pesticide that jeopardizes a threatened or endangered

46. Mary Jane Angelo, The Killing Fields: Reducing the Casualties in the Battle Between U.S. Endangered Species and Pesticide Law, 32 HARV. ENVTL. L. REV. 96, 110 (2008).

47. Id. at $110-17$.

48. Id, at 135 .

49. Id. at 139-40.

50. See supra pp. 5-6. 
species. ${ }^{51}$ Accordingly, it may be in violation of the ESA. On the other hand, if EPA chooses to comply with the ESA and deny or severely restrict a registration, EPA could be vulnerable to legal challenges for not properly implementing its FIFRA mandate to consider economics in its registration decisions. ${ }^{52}$ Moreover, because pesticides are by their very nature intended to kill organisms in the environment, and because there is habitat for the more than 1800 listed species throughout a wide and vast range of the territory of the United States, strict compliance with the ESA under the existing FIFRA framework could result in EPA banning or severely restricting a large number of currently registered pesticides. Such an interpretation would lead to the ESA virtually swallowing up FIFRA. This dilemma is likely a large contributor to EPA's ongoing reluctance to comply with the ESA in implementing its pesticide registration program. ${ }^{53}$

It should be noted that although the standards of the ESA and FIFRA are not easily reconcilable, FIFRA does provide EPA with limited express authority to take certain regulatory action to protect listed species. Specifically, as described above, Section 6(c) of FIFRA authorizes EPA to suspend the registration of a pesticide if necessary to prevent an "imminent hazard" during the time required for a cancellation proceeding. ${ }^{54}$ FIFRA Section 2(1) defines the term "imminent hazard" to include a "situation which exists when the continued use of a pesticide during the time required for cancellation proceeding... will involve unreasonable hazard to the survival of a species declared endangered or threatened by the Secretary pursuant to the Endangered Species Act of $1973 \ldots . . .55$ Under this standard, EPA clearly has the authority to suspend a registration to address hazards to listed species. Accordingly, EPA could bring a suspension action to prevent the extirpation of a listed species from the use of the pesticide. However, nothing in FIFRA indicates how listed species concerns should be addressed under the costbenefit standard for registration or cancellation.

As with the ESA, the MBTA's standards are not easily reconcilable with those of FIFRA. First, the MBTA imposes a strict liability standard

51. Angelo, supra note 46 , at 135 .

52. Id.

53. Id.

54. Federal Insecticide, Fungicide, and Rodenticide Act $\S 6(c), 7$ U.S.C. $\S 136 \mathrm{~d}(\mathrm{c})(1)(2012)$.

55. 7 U.S.C. $\S 136(l)$. 
for takes of migratory birds. ${ }^{56}$ Courts have applied this strict liability standard to pesticide-related bird deaths. ${ }^{57}$ This strict liability standard is in direct conflict with the explicit balancing decisions required for FIFRA pesticide registration. As one author has stated, "[R]egular repeated bird kills might ... [be] tolerated had the benefits of the pesticide in question been greater." 58 Moreover, as with the ESA, and as others have noted, pesticide labeling under FIFRA does not on its own protect migratory birds from poisoning..$^{59}$

In addition to the conflicting standards of the ESA and FIFRA, the differing focuses of the two statutes create incompatibility. "FIFRA creates a national registration process, while the ESA... evaluates individual actions' impacts on a specific habitat and species." 60 The ESA is concerned with preventing injury to individual members of each listed species, and with preventing significant modifications to the habitat of each listed species that would result in injury to the members of the species. ${ }^{61}$ Such modifications include habitat modifications that impact breeding and nesting, activities that typically occur in specific geographic locations during specific times of the year for each species. ${ }^{62}$ The ESA is also concerned with preventing injury to designated critical habitat, which by its very nature is geographically defined. ${ }^{63}$ Accordingly, the ESA is geographically and temporally focused.

In contrast, under FIFRA:

A decision on whether to register or cancel a pesticide is made on a nationwide basis without any real consideration of specific geographic or temporal factors. For example, a particular pesticide may easily meet the cost-benefit registration standard because on a nationwide basis the benefits of the pesticide exceed the environmental or health costs.

56. See Pierre Mineau, Birds and Pesticides: Are Pesticide Regulatory Decisions Consistent with the Protection Afforded Migratory Bird Species Under the Migratory Bird Treaty Act?, 28 WM. \& MARY ENVTL. L. \& POL'Y REV. 313, 329-31 (2004).

57. United States v. FMC Corp., 572 F.2d 902 (2d Cir. 1978).

58. Mineau, supra note 56 at 332.

59. Id. at 338. In this article, the author concludes that because MBTA's provisions relate only to direct, lethal pesticide exposures, they do not fully address the problem. Id. at 335 .

60. Angelo, supra note 46, at 136. See also, Mary Jane Angelo, Embracing Uncertainty, Complexity, and Change: An Eco-pragmatic Reinvention of a First-Generation Environmental Law, 33 ECOLOGY L.Q. 105 (2006).

61. See Babbitt v. Sweet Home Chapter of Cmtys. for a Great Or., 515 U.S: 687 (1995).

62. Id.

63. Endangered Species Act $\S 4,16$ U.S.C. $\$ 1533$ (2012). 
However, this decision ignores the fact that the pesticide may pose substantial risks to a particular listed species that nests in a particular geographic location during certain times of the year. Although in theory, such geographic and temporal concerns could be addressed through label restrictions directing users not to use the pesticide in certain geographic locations during certain times of the year, the reality is that they would be extremely unwieldy. It would be extremely unlikely that EPA could require such detailed label restrictions on every pesticide product to address every geographic or temporal restriction needed to protect every listed species in the entire United States. Moreover, even if EPA did require such detailed label restrictions, it is unlikely that a pesticide user would take the time to read these complex restrictions, determine which if any restrictions apply to the user's intended use in a given location and at a particular time for each and every listed species that may be affected, let alone actually comply with such restrictions. Moreover, monitoring users to ensure they comply with the label restrictions and enforcing against those who did not would be virtually impossible.

Finally, the ESA and FIFRA are inconsistent in that they provide for very different risk reduction methods. Under the ESA, the FWS or NMFS will issue, as part of a $\mathrm{BiOp}$. . . an incidental take statement, which identifies actions that will not be considered to be prohibited takings [under Section 9]. The incidental take statement specifies the reasonable and prudent measures that must be implemented to minimize the risk of takes. ${ }^{64}$

Unless these measures are complied with, any resulting takes will be a violation of the Act. These reasonable and prudent measures typically are very detailed, species-specific, geographically defined, and temporally defined. ${ }^{65}$ As described above, FIFRA's mechanisms for regulating use of pesticides to reduce risk are label restrictions." ${ }^{66}$ Imposition of detailed reasonable and prudent measures set forth in incidental take statements in BiOps is impracticable and unlikely to result in widespread compliance by purchasers and users of pesticides. ${ }^{67}$

In 2005, in Washington Toxics Coalition v. EPA (WTC), ${ }^{68}$ the Ninth Circuit Court of Appeals upheld a lower court's ruling that EPA had

64. Angelo, supra note 46 , at 136.

65. Id. at 137 .

66. Id.

67. See id.

68. Wash. Toxics Coal. v. EPA, 413 F.3d 1024 (9th Cir. 2005), cert. denied sub nom. Croplife Am. v. Wash. Toxics Coal., 546 U.S. 1090 (2006). 
violated the ESA by failing to take steps to ensure that the registration of fifty-four pesticides would not jeopardize the survival of listed salmon species. The court rejected EPA's attempt to circumvent ESA consultation in making regulatory decisions under FIFRA.${ }^{69}$ EPA asserted that it was bound only to apply the provisions of FIFRA, which had limited statutory language relating to listed species. Specifically, 7 U.S.C. $\S 136 \mathrm{~d}(\mathrm{c})(1)-(2)$ authorize EPA to suspend the registration of a pesticide for an immiment hazard, which can include its effect on endangered species. ${ }^{70}$ EPA maintained that it did not have an independent duty under the ESA to undergo consultation on pesticide regulatory decisions. ${ }^{71}$ The Ninth Circuit rejected EPA's arguments, finding that that FIFRA does not allow EPA to exempt itself from the requirements of the ESA, and that the ESA requires EPA to comply with the Section 7 consultation requirements wherever its registration of a pesticide will affect listed species. ${ }^{72}$

This ruling made clear that EPA' could not ignore its ESA obligations, despite the discordances between FIFRA and the ESA and the practical challenges of implementing ESA requirements through the FIFRA regulatory process. ${ }^{73}$ The WTC decision requiring EPA to comply with the ESA was not the end of the matter. EPA and the Services continued to struggle with how to reconcile two statutes with differing purposes and standards. ${ }^{74}$ Having a court declare that the statutes are reconcilable did not automatically guide the agencies in navigating the numerous disparities in the statutes and in the manner in which the agencies interpret and implement the statutes.

A significant challenge to reconciling FIFRA and ESA objectives and processes is the cultural and institutional difference between the unit of EPA that implements FIFRA, the Office of Pesticide Programs (OPP), and the Services. Many units within EPA had an environmental protection

69. Id.

70. Id. at 1031 .

71. See id. After the WTC case, in what is commonly referred to as the "mega ESA litigation," the Ninth Circuit limited the requirement for ESA consultation on regulatory actions under FIFRA to those actions, such as initial registration of a pesticide, that comprise affirmative action. Ctr. for Biological Diversity v. EPA, 847 F.3d 1075 (9th Cir. 2017). The court also found that continued discretionary control and involvement in a pesticide registration did not constitute "ongoing agency action" sufficient to trigger consultation. Id. at 1090.

72. See Wash. Toxics Coalition, 413 F.3d at 1031-32.

73. $I d$.

74. Angelo, supra note 46, at 113-16. 
culture and focus from the outset. In contrast, OPP's origins were in the U.S. Department of Agriculture (USDA). When EPA was established in 1970 , pesticide regulation authority and staff were transferred from the USDA to EPA's OPP. ${ }^{75}$ The USDA's purposes of advancing and supporting agriculture became part of the OPP culture. ${ }^{76}$ Although OPP is required by statute to consider ecological impacts in its FIFRA decision-making, ${ }^{77}$ its origins and continuing cultural identity fall more squarely in supporting agricultural interests and human health protection than in ecological protection. In fact, a longstanding, significant conflict between EPA's approach to ecological risk assessment under FIFRA and the Services' approach under the ESA was that EPA focuses on adverse impacts to individual members of a species (e.g., how toxic a particular pesticide to individuals of a particular species) rather than looking at population or ecosystem-wide impacts (e.g., whether a particular pesticide will significantly reduce a population of a particular species whose reduction will have significant impacts to the ecosystem by, for example, reducing predation that normally would occur on species lower on the food chain). ${ }^{78}$

To help resolve the regulatory discordance and disparities in the institutional approaches of EPA and the Services, in 2011 EPA and the Departments of Agriculture, Commerce, and the Interior required that the National Research Council of the National Academies convene a committee of independent experts to weigh in on a range of issues related to tools and approaches to reconcile EPA and the Services' approaches to assessing the effects of proposed regulatory actions under FIFRA on endangered and threatened species. ${ }^{79}$ The Committee recommended that the agencies adopt a common approach to ecological risk assessment rather than each employing their own approach. ${ }^{80}$ The Report outlined an

75. Reorganization Act of 1970, Pub. L. No. 91-510, 84 Stat. 1140 . Prior to the creation of EPA in 1970, the USDA was responsible for administering FIFRA. In 1970, these responsibilities were transferred to EPA.

76. One of USDA's stated goals is to promote agricultural production. See About the U.S. Department of Agriculture, U.S. DEP'T OF AGRIC., https:/www.usda.gov/our-agency/about-usda (last visited Aug. 21, 2018).

77. 7 U.S.C. $\$ \$ 136(\mathrm{bb}), 136 \mathrm{a}(\mathrm{a})(2012)$.

78. COMM. ON ECOLOGICAL RISK ASSESSMENT UNDER FIFRA AND ESA, NAT'L RESEARCH Council, Assessing Risks to Endangered AND THREATENEd SPECIES From Pesticides (2013).

79. Id. at ix-xi.

80. Id. at 5-8. 
ecological assessment process and described how conflicts could be avoided if the Services would build on EPA's analysis of whether a pesticide is likely to adversely affect a listed species, rather than conducting a completely new analysis. ${ }^{81}$ The Report also recommended, among other things, improved communication and coordination throughout the ecological assessment process. ${ }^{82}$

In response to the Report, EPA and the Services developed a white paper, which provides interim guidance for resolving interagency disputes in the pesticide-regulation process. ${ }^{83}$ The white paper explains the common process the agencies intend to use and describes how the agencies will improve coordination. The agencies' agreement to use a common approach rather than working at cross-purposes is a significant development. This interim approach moves the ball forward in terms of having a coordinated, consistent framework between EPA and the USDA, particularly with regard to the consultation process and the specifics of ecological risk assessment. ${ }^{84}$ However, the approach does not specifically address the broader issue of the differences between the two statutes. It remains to be seen whether the proposed approach to the ecological risk assessment and the consultation processes are adequate to avoid future conflicts. For example, it is not clear what might happen if the services make a jeopardy determination for a pesticide that EPA believes meets the FIFRA "unreasonable adverse effects" ${ }^{" 85}$ standard for registration.

\section{Mulitple Conflicting Statutes: The Everglades Example}

The examples described above involve conflicts between two distinct agencies and the environmental laws applicable to them. Conflicts among multiple environmental laws with related but differing objectives also arise. In particular, complex, large-scale environmental restoration projects often invoke multiple environmental laws. One of the most obvious places this has occurred is in the context of Everglades

81. Id.

82. Id.

83. U.S. ENVTL. PROTECTION AGENCY ET AL., INTERIM APPROAChES FOR NATIONALLEVEL PESTICIDE ENDANGEREd SPECIES ACT ASSESSMENTS BASED ON THE RECOMMENDATIONS OF THE NATIONAL ACADEMY OF SCIENCES APRIL 2013 REPORT (2015), https://www.epa.gov/sites/ production/files/2015-07/documents/interagency.pdf.

84. Id.

85. 7 U.S.C. $\$ 136(\mathrm{bb})$. 
restoration. ${ }^{86}$ The Everglades comprise a vast and extremely complex ecosystem, which has been substantially altered and managed by humans beginning in the late-nineteenth century, when large portions of the system were drained to "improve" them for human use. The most significant alterations occurred in the mid-twentieth century, when the U.S. Congress authorized the Central and Southern. Florida (C\&SF) Project, which was designed to provide flood control and agricultural water supply. ${ }^{87}$ Decades of work resulted in an extensive, highly engineered system of ditches, dikes, water control structures, and pumps, which are actively operated through a sophisticated control system. ${ }^{88}$

Attempts to reverse and restore the Everglades have been ongoing for decades. Everglades restoration efforts are challenging given the complex nature of the ecosystem. Each component of the Everglades is connected to other parts such that even a minor change in any part could greatly affect other locations. ${ }^{89}$ Restoration is further complicated by the decades of engineering coupled with dramatic urban development and agricultural development. ${ }^{90}$ Due to the complexity of the Greater Everglades Ecosystem and the vast area of land and water encompassed within it, restoration must take place within the context of extensive state and federal laws that govern various aspects of natural resource protection. ${ }^{91}$ Agencies involved in the planning and implementation of restoration projects must negotiate a labyrinth of complex legal requirements, at times at odds with each other. ${ }^{92}$ The most significant and challenging issues with restoration come into play when two or more federal environmental laws seemingly clash. Of greatest concern are the

86. The author is a member of the National Academies, National Rescarch Council Committec on Independent Scientific Review of Evcrglades Restoration Progress. Although this Article uses Everglades restoration as one of several examples where multiple and sometimes conflicting statutory objectives have complicated restoration efforts, this Article is not intended to provide an analysis of legal issues related to Everglades restoration. Similarly, this article is not intended to attempt to resolve or comment on legal conflicts related to Everglades restoration.

87. NRC Report 2016, supra note 27, at 22-23.

88. Id.

89. See Wendy D. Graham et al., Options to Reduce high Volume freshwater Flows to the St. Lucie and Caloosahatchee Estuaries and Move More Water from LAKE OKEECHOBEE TO THE SOUTHERN EVERGLADES 5-7 (2015).

90. Id. at 26.

91. NRC Report 2012, supra note 6, at xi-xii.

92. See, e.g., id. at 6 ("A recent conflict betwecn efforts to protect snail kite nests and [stormwater treatment area] operations illustrates how single species management could potentially compromise water management required for system restoration.") 
sometimes-contradictory requirements of the CWA, ESA, and MBTA. These conflicts are often cited as constraints on restoration..$^{93}$ Legal requirements related to restoration efforts have pitted CWA water quality concerns against overall ecosystem restoration and protection or recovery of ESA-listed species and MBTA-protected species, protection of protected species against protection of other species, and protection of water quality within the Everglades National Park against protection of estuary and coastal water quality. ${ }^{94}$

Everglades restoration is further complicated by the multiple and diverse objectives of numerous stakeholder groups, including restoring a functioning ecosystem, providing water for agricultural irrigation, providing public water supply to an ever-increasing population along the south Florida coasts, preserving sacred tribal lands and resources utilized by the Seminole and Miccosukee tribes, and preventing flooding of urban and agricultural areas. ${ }^{95}$ It is virtually impossible for any Everglades restoration plan to optimize all objectives of each of these stakeholders. Consequently, Everglades restoration efforts have been faced with a series of roadblocks, in many cases resulting from disparate environmental statutory or regulatory requirements or from the way courts have interpreted and implemented these requirements. ${ }^{96}$

The most contentious legal issues in Everglades restoration have involved compliance with water quality standards (WQS) established under the CWA. ${ }^{97} \mathrm{~A}$ conflict arises when compliance with these CWA requirements may cause a "take" or adversely affect a species or the habitat of a species listed under the ESA or result in a "take" of a species protected by the MBTA. These conflicts can arise in a number of circumstances. Litigation under the CWA resulted in a consent decree and permit requirements that dictate when and where water can be released into the Everglades. Too many, too few, or inappropriate timing of water

93. See, e.g., Lance H. Gunderson ct al., Regime Shifts and Panarchies in Regional Scale Social Ecological Water Systems, 22 ECOLOGY \& SOC'Y 1, 4 (2017); Lance H. Gunderson et al., Escaping a Rigidity Trap: Governance and Adaptive Capacity to Climate Change in the Everglades Social Ecological System, 51 IDAHO L. REV. 127, 137 (2014).

94. See Gunderson et al. (2017), supra note 93, at 4; Gunderson et al. (2014), supra note 93, at 137 .

95. GRAHAM ET AL., supra note 89 , at 21.

96. NRC Report 2012, supra note 6, at 32-36.

97. See $i d$. at 35 ("One of the most significant challenges to Everglades restoration is the inability to distribute treated water from the [stormwater treatment arcas] into the Everglades Protection Area if that water leads to violations of legally mandated water quality standards."). 
releases can adversely impact species, including those protected by the ESA and MBTA. For example, releasing too much water or impounding water in certain areas of the Everglades during nesting season can destroy bird nests and kill or injure hatchlings. In other cases, insufficient water resulting from CWA compliance activities can harm certain species. ${ }^{98}$

The conflicts between the requirements of the CWA, the ESA, and the MBTA have arisen in several contexts in Everglades restoration. A significant challenge to progress in restoring the Everglades relates to the differing objectives and requirements of the ESA and those of the CWA. The CWA articulates a goal of restoring the chemical, physical, and biological integrity of surface waters. ${ }^{99}$ The primary CWA regulatory program is the National Pollutant Discharge Elimination System (NPDES) permitting program. NPDES permits are required for any discharge of a pollutant from a point source into waters of the United States. ${ }^{100}$ NPDES permits must ensure that two types of standards are met: first, technology-based standards determined by the availability, cost, and feasibility of existing technology; and second, water quality-based standards, established by the states to protect designated uses of waters. ${ }^{101}$ Effluent limitations for both types of standards are incorporated into NPDES permits; an exceedance of a limitation violates the CWA. ${ }^{102}$ Water quality standards and NPDES permit conditions have, in some circumstances, created potential conflicts with wildlife protection statutes. The ongoing restoration efforts in Florida's Everglades described below are illustrative of this issue.

The primary focus of Everglades restoration is to restore the hydrology of the system to something approaching its pre-drained condition. ${ }^{103}$ To accomplish that goal, water previously diverted out of the Everglades must be returned. However, currently, that water is highly polluted with phosphorus and other pollutants from agricultural run-off and does not comply with water quality standards established for the Everglades under the CWA. ${ }^{104}$ Restoration of hydrology is critical to

98. Id. at 100-03.

99. 33 U.S.C. § 1251(a) (2012).

100. Id. $\S \S 1311(\mathrm{a}), 1342(\mathrm{a})(1)-(5)$.

101. Id. $\S \S 1311,1313$.

102. Id. $\S 1319$.

103. See Water Resources Development Act of 2000, Pub. L. No. 106-541, §601, 114 Stat. 2572, 2680-93.

104. See NRC Report 2012, supra note 6, at 113-22, 223-30. 
recovering populations of endangered and threatened species in the Everglades. ${ }^{105}$ Many Everglades species, including some threatened and endangered species, existed prior to the draining of the system. ${ }^{106}$ Other species that depend on drier conditions appear to have found new habitat in the post-drained conditions. Consequently, efforts to restore hydrology may adversely affect species that have come to rely on the human-created drier habitat. ${ }^{107}$

Two significant federal lawsuits brought under the CWA have made clear that any water redistributed through the Everglades to promote the hydrologic restoration of the ecosystem must meet established water quality standards. In the first of these lawsuits, United States v. South Florida Water Management District, the United States sued Florida, alleging that Florida's lack of enforcement of water quality laws threatened the water quality of Everglades National Park and the Loxahatchee National Wildlife Refuge. ${ }^{108}$ After much legal wrangling between the federal and state governmental agencies, the parties reached a settlement, and, in 1992, approved a complex consent decree that requires the State of Florida take actions to ensure all discharges to the Park and the Refuge meet specified phosphorus limitations. ${ }^{109}$ 'To accomplish this requirement, Florida committed to building and operating thousands of acres of created wetlands, known as Stormwater Treatment Areas (STAs), and to implementing a regulatory program to reduce phosphorus waste from the farms that discharge into the Everglades. ${ }^{110} \mathrm{~A}$ modified consent decree that extends the deadline for compliance with phosphorus standards from 2002 to 2006 remains in effect and under the jurisdiction of the court. ${ }^{11}$ To date, Florida's extensive and costly efforts to reduce phosphorous levels have not achieved compliance with the levels set forth in the consent decree. ${ }^{112}$ During this time, some restoration efforts have stalled because Florida fears violating the consent decree by

105. Id. at 22 .

106. See id. at 64-66 (identifying the ESA-listed Wood Stork and Snail Kite as species that are highly dependent on the ecological conditions that were characteristic of the undrained south Florida landscape).

107. See NRC Report 2016, supra note 27, at 63-70.

108. Settlement Agreement, United States v. S. Fla. Water Mgmt. Dist., 847 F. Supp. 1567

(S.D. Fla. 1992) (No. 88-1886-CIV-HOEVLER) [hercinafter "Settlement Agreement"].

109. Id. at $9-11, \mathrm{~A}-1-\mathrm{A}-4$.

110. Id. at $17-20$.

111. Id.

112. NRC Report 2016, supra note 27, at 5. 
discharging water not in compliance with the phosphorous levels into the Park or Refuge.

The second of the two significant federal lawsuits involved a challenge to the EPA's approval of Florida's water quality standards. ${ }^{113}$ In response to a 2012 court order, Florida agreed to expand the STAs to provide additional water quality treatment. An NPDES permit, which includes a water quality-based effluent limitation (WQBEL), was issued for discharges from the STAs to the Everglades. ${ }^{14}$ More than twenty years of planning have been dedicated to improving water quality through the construction of STAs costing more than 1.8 billion dollars. ${ }^{115}$ Although these efforts have greatly.reduced phosphorous concentrations in discharges from the STAs, the discharges do not yet comply with the WQBEL. ${ }^{16}$ Until discharges from the STAs are brought into compliance with water quality standards, most of the Everglades ecosystem will continue to suffer from being starved of the water that it needs to function effectively. ${ }^{117}$ This degradation has adversely affected species ostensibly protected by both the ESA and the MBTA. ${ }^{118}$

An unanticipated byproduct of CWA-required water quality treatment is that ESA- and MBTA-protected species have nested in the STAs that Florida constructed to comply with the CWA's water quality standards, permits, and the consent decree. ${ }^{119}$ Florida has spent more than 1.8 billion dollars to construct these vast acreages of STAs and associated FEBs, which are designed to remove phosphorous to ensure compliance with water quality standards. ${ }^{120}$ These areas represent "new wetlands," which have become nesting grounds for several bird species, including the endangered Snail Kite and the MBTA-protected Black-Necked Stilt. ${ }^{121}$ Once these birds build nests in the STAs, the STAs cannot be operated

113. Miccosukee Tribe of Indians of Fla. v. United States, No. 04-21448-CIV, 2006 WL 648055 (S.D. Fla. Fcb. 16, 2006).

114. NRC Report 2016, supra note 27, at 62; NAT'L RESEARCH COUNCIL, Progress TOWARD RESTORING THE EVERGLADES: THE FIFTH BIENNIAL REVIEW 101-02 (2014) (hereinafter NRC Report 2014).

115. Improving Everglades Water Quality, SOUTH FLA. WATER MGMT. DIST. https://www.sfwmd.gov/our-work/wq-stas (last visited Mar. 7, 2019).

116. NRC Report 2016, supra note 27, at 4-5.

117. NRC Report 2012, supra note 6, at 100-03, 141-46.

118. Id. at 141-46.

119. NRC Report 2016, supra note 27, at 63-66.

120. Improving Everglades Water Quality, supra note 120.

121. NRC Report 2016, supra note 27, at 63. 
normally without flooding the nests, which could be considered a "take" under the ESA or MBTA. ${ }^{122}$ When a protected species nests in an STA or FEB, a conflict could arise over whether the STA or FEB must be managed to protect the species even if such management would result in less effective water quality treatment. ${ }^{123}$

Concerns about these species nesting in STAs are not merely theoretical. One or both species nested in all five STAs in 2015, and there have been as many as 113 Snail Kite nests and 204 Stilt nests in STAs during recent breeding seasons. ${ }^{124}$ The Black-Necked Stilt constructs its nests at the end of the dry season in STA cells that contain little or no water. ${ }^{125}$ Normally these cells would naturally refill during the rainy season, which would destroy any Stilt nests present. ${ }^{126}$ The endangered Snail Kite, on the other hand, builds its nests during wet years in emergent vegetation in STAs that contain water of sufficient depth. ${ }^{127}$ To nest successfully, both birds require a suitable rate of water recession; nests can be destroyed by either too much inflow or too much outflow. ${ }^{128}$ Accordingly, due to ESA and MBTA concerns, the presence of nesting Stilts or Kites restricts water managers' ability to move water in and out of STAs to optimize water quality treatment. ${ }^{129}$ Without optimal water treatment, the rehydration of the Everglades that is necessary for the restoration of the ecosystem as a whole and for the recovery of other species will be delayed even further.

Prior to the construction of the STAs, the action agencies consulted with the FWS under the ESA. However, because the parties did not anticipate that Snail Kites would nest in the STAs after they were constructed, the consultation did not address this concern. ${ }^{130}$ As described above, FWS is not authorized to take Stilts under the MBTA. ${ }^{131}$ Therefore, to comply with the take prohibitions in both the ESA and MBTA, the state must operate the STAs in ways that can deviate from

122. Id. at $63-64$.

123. Id. at 64 .

124. Id. at 63-64.

125. Id. at 63 .

126. $I d$.

127. Id.

128. $1 d$.

129. Id. at 63-64.

130. Id. at 64 .

131. Id. 
optimal STA operations designed to meet water quality standards. After it became apparent that Stilts were nesting in STAs, an Avian Protection Plan $^{132}$ was developed to protect the Stilts and provide guidance on operation of STAs to avoid creating additional nesting habitat that could create conflicts. Data are not yet available to quantify the extent to which STA functioning has been affected by operations that have been modified to protect nests. ${ }^{133}$

In addition to creating the specific conflict between species protection and CWA requirements, Everglades restoration efforts create several potential conflicts between ecosystem-wide restoration goals and the habitat requirements of specific protected species. ${ }^{134}$ The greater Everglades ecosystem has been dramatically altered by past efforts to drain south Florida land for agriculture and development. ${ }^{135}$ For more than a half century, much of the formerly wet Everglades has been relatively dry. ${ }^{136}$ During this long period, species adapted to wet conditions (such as the Snail Kite) have moved out of previously wet habitat, while species adapted to drier conditions (such as the Cape Sable Seaside Sparrow) have moved into drained drier areas. ${ }^{137}$ The primary objective of Everglades restoration is to restore the hydrology of the system to something close to its original state before human intervention. ${ }^{138}$ Meeting this objective will benefit many species and will improve the ecosystem functions of the Everglades in general, but restoration may cause harm to those species already adapted to the altered conditions. ${ }^{139}$

Ultimately, restoration of the Everglades is expected to provide substantial benefits to populations of a wide range of species, including listed species, while restoring important ecosystem functions on a vast scale. Nevertheless, in the course of undertaking certain restoration projects, including rehydrating some highly drained areas, some species will suffer. Although restoration may provide sufficient widespread benefits to justify some harms to select species or resources, complete

132. Pandion Sys., InC., AVIAN Protection Plan fOr BlaCk-NeCKed Stilts and Burrowing OWls Nesting in the Everglades Agricultural area Stormwater TREATMENT AREAS (2007).

133. NRC Report 2016, supra note 27, at 64.

134. NRC Report 2012, supra note 6, at 6.

135. Id. at $19-21$.

136. Id.

137. Id. at 63-64.

138. Id at 22-23.

139. Id. 
restoration will take decades, and there may be transitory effects on important species and resources.

The potential for conflicts among protected species is demonstrated by a recent lawsuit alleging that water management practices around Everglades National Park jeopardize the continued existence of the Cape Sable Seaside Sparrow, an endangered species currently residing in the park. The sparrow requires drier habitat than that which existed prior to drainage of the park. Efforts to restore the park's hydrology to its predrainage condition will benefit the ecosystem and numerous species, but it will likely negatively impact the sparrow's remaining habitat. Protecting the sparrow's habitat, on the other hand, will likely negatively impact the Snail Kite and other protected species, such as the Wood Stork and the Roseate Spoonbill. Even if a long-term solution that protects all of these species can be developed, there will likely be negative impacts to some protected species during the transition from the current conditions to the restored conditions. For these reasons, the Services issued a jeopardy finding for "The Everglades Restoration Transition Plan," which governs this transition period. ${ }^{140}$

The Everglades example illustrates a particular challenge of largescale environmental restoration projects: Environmental protection statutes often conflict. This is most apparent where more than one species protected by the ESA or MBTA have different habitat or resource needs. Where ecosystems have been altered by humans, restoration efforts may pit species adapted to the altered conditions against species adapted to pre-alteration conditions. Consequently, attempts to restore habitat for one species, or for the benefit of the ecosystem as a whole, may inadvertently harm other protected species. For decades, scientists and policymakers had advocated multi-species management approaches that focuses on ecosystems or landscapes rather than on individual species. The U.S. Fish and Wildlife Service has long recommended the use of multi-species approaches where species are taxonomically-related and face similar threats or share an ecosystem. ${ }^{141}$ Other approaches to multispecies protection include the umbrella concept, in which conserving the habitat for one species with a large habitat range will necessarily protect

140. U.S. ARMY CORPS OF ENG'RS, EVERGLADES RESTORATION TRANSITION PLAN FINAL ENVIRONMENTAL IMPACT STATEMENT 4-53 to -76 (2011).

141. Susan D. Jewell, Multi-Species Recovery Plans, ENDANGEREd SPECIES BULL., MayJune 2000 , at 30 . 
species with narrower habitats within the wider range. ${ }^{142}$ Another approach is to protect the species most vulnerable to a particular threat, under the assumption that species less sensitive to that threat will also be protected. ${ }^{143}$ While these multi-species approaches may be successful in some situations, scientific research suggests that it is not uncommon for closely related species to have very different responses to similar threats or protection efforts. ${ }^{144}$ Instead, the most successful multi-species recovery plans typically involve species that respond similarly to the threats they face. ${ }^{145}$ Thus, while multi-species biological opinions, recovery plans, or other environmental management plans may be effective in some circumstances, they do not contain the tools necessary to address the challenges of attempting to protect multiple species where particular action may benefit one species but harm another. This challenge becomes more profound when managers attempt to restore areas where human activity has shifted the species composition of a habitat. In this situation, attempts to restore an ecosystem to its pre-anthropogenic state could negatively affect the current habitat residence. Even where the restoration will ultimately provide widespread benefits, individual species may be harmed, or some species may suffer during the transition period of the restoration.

\section{HARMONIZING THE DISCORDANT}

\section{A. Resolution of Conflict in the Courts}

Courts are frequently called upon to resolve conflicting statutory provisions. Applying basic canons of statutory construction, courts may find that a later statute impliedly repealed a conflicting earlier statute. However, courts seek to avoid such a reading except where the later statute clearly contradicts the earlier statute and it is impossible to interpret the statutes to avoid the conflict. ${ }^{146}$ Courts may also apply a

142. Brain G. Laub \& Phaedra Budy, Assessing the Likely Effectiveness of Multispecies Management for Imperiled Desert Fishes with Niche Overlap Analysis, 29 CONSERVATION BIOLOGY 1153, 1154 (2015).

143. Id.

144. $I d$.

145. Id.

146. See, e.g., Morton v. Mancari, 417 U.S. 535, 551 (1974) ("The courts are not at liberty to pick and choose among congressional enactments, and when two statutes are capable of coexistence, it is the duty of the courts, absent a clearly expressed congressional intention to the contrary, to regard each as effective."). 
presumption against absurd results to avoid certain statutory conflicts, but there is a high threshold for finding absurdity. ${ }^{147}$ In many situations, canons of statutory construction will not be useful, and courts will engage in more narrowly tailored legal analyses to resolve conflicts.

The ESA applies to all federal agencies regardless of the organic statute under which they operate or the objectives they seek to achieve. Thus, since the ESA's inception, environmental regulators and courts have both struggled with the issue of whether, or to what extent, the ESA trumps other federal laws. A few federal court decisions, including two by the U.S. Supreme Court, address the interplay between the ESA and other federal environmental laws in certain limited circumstances. For quite some time, federal circuit courts were split on whether the ESA's consultation and no-jeopardy requirements are absolute and whether they apply even where a federal agency lacks the authority to comply with them. Although the ESA provides for no explicit limit on the consultation requirement, the Services regulations limit ESA consultation to federal actions "in which there is discretionary Federal involvement "or control." $" 148$ Early decisions by the D.C. Circuit ${ }^{149}$ and Fifth Circuit ${ }^{150}$ found that Section 7 does not provide authority beyond that provided in the statute underlying the agency action. The First Circuit ${ }^{151}$ and Eighth Circuit, ${ }^{152}$ on the other hand, took the position that the ESA grants additional authority for federal agencies to comply with the ESA even where no such authority exists in those agencies' implementing statutes.

147. See, e.g., Pub. Citizen v. United States Dep't of Justice, 491 U.S. 440, 470-71 (1989) (Kennedy, J., concurring) (suggesting that clear statutory language is absurd only where it is virtually impossible that the absurd interpretation is what Congress intended).

148. 50 C.F.R. $\$ 402.03$ (2018).

149. Platte River Whooping Cran Critical Habitat Maintenance Trust v. F.E.R.C., 962F.2d 27, 34 (D.C.Cir. 1992) ("the statute directs agencies to "utilize their authorities" to carry out the ESA's objectives; it does not expand the powers conferred on an agency by its enabling act."). For a detailed description of these early cases, see Alicia D. Kisling, Environmental Law - A Tale of Two Conflicting Mandates: Limiting Agency Authority Under the Endangered Species Act or Resolution of the Statutotry Overlap?, National Association of Homebuilders v. Defenders of Wildlife 127 S.Ct. 2518, 8 WYOMING L. REV. 481, 489-93 (2007) and Sherry L. Bosse, Defenders of Wildlife v. EPA: Testing the Boundaries of Federal Agency Power Under the ESA, 36 ENVTL L 1025, 1047-54 (2006).

150. Am. Forest \& Paper Ass'n v. EPA, 137 F.3d 291, 299 (5th Cir. 1998). ("[T]he ESA serves not as a font of new authority, but as ... a directive to agencies to channel their existing authority in a particular direction.").

151. Conservation Law Foundation of New England, Inc. v. Andrus, 623 F.2d 712, 715 (1st Cir. 1979).

152. Defenders of Wildlife v. EPA, 882 F.2d 1294, 1299 (8th Cir. 1989). 
In the 2004 Washington Toxics Coalition case described above, the Ninth Circuit addressed this issue in the context of the different standards in the ESA and FIFRA. The court found that, while the ESA and FIFRA have different purposes and different metrics, EPA could not ignore its responsibilities under the ESA simply "because it is bound to comply with another statute that has consistent, complementary objectives." 153

In 2007, the U.S. Supreme Court addressed the issue of an agency's consultation authority in the context of the ESA and CWA. In National Association of Home Builders v. Defenders of Wildlife (NAHB) ${ }^{154}$ the Court decided the narrow issue of whether the EPA was required to consult with the FWS under the ESA in determining whether to delegate the CWA's NPDES program to the State of Arizona. On its face, the ESA requires consultation for any federal action that may affect listed species, while the CWA provides that EPA "shall" transfer NPDES authority to a state provided that the state meets nine specific criteria enumerated in the CWA. The Court upheld the services position in holding that, notwithstanding the ESA's clear mandate, consultation is only required for discretionary agency actions. ${ }^{155}$ The specific issue in the case was whether the EPA, in determining whether to delegate the NPDES authority to a state, was required to undergo Section 7 consultation. The Court described the conflict between the CWA, which requires that EPA "shall" delegate the NPDES program to a state provided that the state meets nine specifically articulated criteria, and the ESA, which contains consultation and no-jeopardy requirements, as a "clash of seemingly categorical-and, at first glance, irreconcilable-legislative comments."156 The Court noted that requiring EPA to undergo consultation when deciding whether to delegate a program would, in essence "repeal the mandatory and exclusive list" of nine criteria found in the CWA and replace it with a new list that includes the ESA's Section 7 consultation requirements. ${ }^{157}$ The Court applied the presumption against implied repeals unless explicitly provided by statute. In reaffirming this presumption, the Court did not find it compelling that the ESA was enacted after the pertinent provision of the CWA. ${ }^{158}$ Further, the Court

153. Wash. Toxics Coal., 413 F.3d at 1032.

154. Nat'l Ass'n of Home Builders v. Defs. of Wildlife, 551 U.S. 644 (2007).

155. Id. at $672-73$.

156. Id. at 661 .

157. Id. at 662 .

158. Id. at 662-64. 
expressed the broader concerns that reading Section 7 of the ESA to trump all federal nondiscretionary actions would potentially override every federal statute that mandates agency action. ${ }^{159}$ Accordingly, the Court found the Section 7 services regulation applies only to federal actions in which there is discretionary federal involvement or control, to harmonizing the ESA and CWA's requirements to "guide agencies' existing discretionary authority, but not read[] it to override express statutory mandates." 160

As others have noted, the circuit split that existed prior to 2007 involved two different situations. The courts that held that the ESA does not confer additional power on federal agencies to comply with the ESA Section 7 requirements were asked to decide the issue under statutes that provided limited discretion or no discretion to the agencies. In contrast, the courts that found the ESA did confer such additional powers addressed the issue in the context of statutes that authorize a federal agency to consider effects on listed species or provide broad discretionary authority to the agency. When considering apparent conflicts between the ESA and other statutes, such as the CWA, FIFRA, or the MBTA, one must determine the extent to which the agency has discretionary authority to comply with the ESA. In making this determination, it is necessary to consider the specific statutory language governing the agency action. In $N A H B$, EPA's authority under the specific section of the CWA left no room for consideration of endangered species. Other statutes and other provisions of the CWA may provide more discretion, or at least are not unambiguously nondiscretionary. This is where things become more complicated.

Courts addressing this issue after $N A H B$ have tended to limit the application of the case to, as Sandra Zellmer describes, "those rare occasions where compliance with both section 7 consultation requirements and the statutory provision in question would be impossible." 161 One post- $N A H B$ example explored by Sandra Zellmer occurred in 2008, when the State of Missouri refused to issue a CWA water quality certification ${ }^{162}$ that was required before the U.S. Army

159. Id. at 664 .

160. Id. at 666 .

161. Sandra Zcllmer, Mudslinging on the Missouri: Can Endangered Species Survive the Clean Water Act?, 16 DRAKE J. AGRIC. L. 89, 109 (2011). See also Malori Dahmen, Note, CWA and ESA: Nine Is a Party, Ten Is a Crowd-National Association of Home Builders v. Defenders of Wildlife, 127 S. Ct. 2518 (2007), 29 ENERGY L.J. 703, 709 (2008).

162. 33 U.S.C. $\$ 1342$ (2012). 
Corps of Engineers could proceed with a habitat restoration plan compelled by an ESA BiOp. Zellmer asserts that, given the similar environmental protection goals of the CWA and the ESA, compliance with the CWA "should complement, not displace, an agency's duties under the ESA." 63

After $N A H B$, an agency's statutory mandate can be very clear-cut if a specific list of statutory criteria (not including ESA compliance) is met. ${ }^{164}$ However, $N A H B$ provides little or no guidance in many harder cases where the agency's statutory authority and the extent of its discretion are less clear. In situations where seemingly conflicting federal statutes contain flexibility mechanisms or provide discretion to implementing agencies, the interplay is murkier and can turn on the federal agency's interpretation of laws, its willingness to employ flexibility mechanisms, and its willingness to exercise prosecutorial discretion.

The $N A H B$ case and the WTC case can be distinguished by the language of the relevant CWA and FIFRA provisions. Section 402(b) of the CWA sets forth an exclusive list of criteria that must be met for EPA to approve a transfer of permitting authority to a state. None of these specified criteria relate to whether an action will jeopardize listed species. Thus, the Court in that case rejected the argument that in applying the criteria, EPA had the authority to impose a completely new criterion addressing potential impacts to listed species. The WTC Court, on the other hand, recognized that, while FIFRA does not expressively mandate that EPA give special consideration to listed species, it does require EPA to consider impacts to wildlife, which would necessarily include listed species. Thus, FIFRA registration decisions are an example of where an agency has discretionary authority to address impacts to listed species and accordingly must comply with ESA.

Court decisions that attempt to reconcile discordant environmental statutes have been less than satisfying. In some cases, statutory construction can resolve a matter; where it would be impossible to comply with both ESA requirements and another statute's requirements, the answer is clear. In most cases, it is not impossible to comply with both, but it is often challenging. Courts have recognized that ESA and other environmental statutes can complement each other, but they have not tackled the difficult issue of how this would actually work, what environmental objectives should have priority, or what principles should

163. Zellmer, supra note 161 , at 108 .

164. Id. at 111 . 
guide agencies in determining whether or how to implement statutory flexibility. Multi-objective optimization can help answer these questions.

\section{B. Multi-Objective Optimization}

Multi-objective optimization is a type of multi-criteria decision- making - an established method used to evaluate multiple conflicting criteria in decision-making. In general, multi-criteria decision-making provides a structured framework that guides decision-makers in complex matters involving multiple criteria. The process involves gathering information from stakeholders, establishing what criteria will be used to judge alternative solutions, determining the relative importance of each criterion, and ultimately deciding on the best alternative solution. ${ }^{165}$ Using this approach ensures stakeholder involvement and transparent decisionmaking. Perhaps more importantly, this approach requires thoughtful, upfront crafting of criteria to judge alternatives, and the relative weight to afford each criterion. Because environmental decision-making inevitably involves tradeoffs between multiple objectives, ${ }^{166}$ a body of scientific literature has proposed a variety of processes and mathematical models designed to address multiple objectives. ${ }^{167}$

Multi-objective optimization takes multi-criteria decision-making a step further by striving to optimize the multiple objectives associated with a problem, typically through mathematical modeling. Multi-objective optimization is an approach that has been used for many years in the business and engineering worlds as a way to find optimal solutions to problems that involve multiple objectives. In this context, optimization

165. Igor Linkov et al., From Optimization to Adaptation: Shifting Paradigms in Environmental Management and Their Application to Remedial Decisions, 2 INTEGRATED ENVTL. ASSESSMENT \& MGMT. 92, 95 (2006).

166. Gregory A. Kiker et al., Application of Mulitcriteria Decision Analysis in Environmental Decision Making, 1 INTEGRATED ENVTL. ASSESSMENT \& MGMT. 95 (2005).

167. See, e.g., Jurgen Branke \& Kalyanmoy Deb, Integrating User Preferences into Evolutionary Multi-Objective Optimization, in KNOWLEDGE INCORPORATION IN EVOLUTIONARY COMPUTATION (Y. Jin, ed., 2005); Matteo Convertino et al., Enhanced Adaptive Management: Integrating Decision Analysis, Scenario Analysis and Environmental Modeling for the Everglades, $3 \mathrm{SCl}$. REP. 2922 (2013); Lucien Duckstein \& Serafim Opricovic, Multiobjective Optimization in River Basin Development, 16 WATER RESOURCES RES. 14 (1980); Robin Gregory \& Katharine Wellman, Bringing Stakeholder Values Into Environmental Policy Choices: A Community-Based Estuary Case Study, 39 ECOLOGICAL ECON. 37 (2001); Maureen C. Kennedy et al., Informed MultiObjective Decision-Making in Environmental Management Using Pareto Optimality, 45 J. OF APPLIED ECOLOGY 181 (2008); Kiker et al., supra note 166; Lothar Thicle et al, A PreferenceBased Evolutionary Algorithm for Multi-Objective Optimization, EVOLUTIONARY COMPUTATION 17(3): 411-436 (2009). 
means identifying the best alternative solution to a problem within an identified set of constraints. Multi-objective optimization provides a structured process for making decisions to optimize multiple objectives. A number of mathematical methods have been developed to optimize multiple objectives. ${ }^{168}$ Despite the evolution of sophisticated multiobjective decision-making models, the literature has not yet grappled with the problem of decision-making where multiple environmental statutes are discordant, either on their face, as interpreted and applied by implementing agencies, or as imposed by courts. This article posits that the basic concept of multi-objective optimization can provide a framework for optimizing multiple legal objectives, even in the absence of quantitative data and sophisticated mathematical modeling. ${ }^{169}$

\section{The basic mechanics of multi-objective optimization}

There are numerous methods to apply MOO in different situations, as well as a variety of mathematical tools that have been developed for quantitative MOO analysis. The basic structure of MOO, however, involves a step-by-step, pre-determined methodology that guides the decision-making process. Each step has its own information needs, with varying degrees of stakeholder and public input. To address multiple statutory objectives that do not focus on quantitative analysis, a MOO analysis could include the following steps:

\section{Step 1: Define and identify multiple desired objectives}

Having a clearly identified and articulated set of objectives is a critical first step in all MOO analyses. Examples of objectives could be protection of endangered species (ESA), improved water quality (CWA), registration of pesticides that do not pose unreasonable adverse effects and play important roles in agriculture or public health protection (FIFRA), protection of migratory birds (MBTA), and any other economic and social factors required to be considered by statute. Identification of all pertinent criteria requires careful analysis of all relevant environmental

168. See, e.g., Ciara Pike-Burke, Multi-Objective Optimization, STOR601: Research Topic I, https://www.lancaster.ac.uk/pg/pikcburc/reportl.pdf (last visited Feb. 28, 2019).

169. This article does not focus on mathematical modeling tools needed to conduct quantitative multi-objective optimization. That discussion is left in the capable hands of the many modelers who undertake such work. Although ultimately development of quantitative analytics for multi-objective optimization in the legal context may prove valuable, this article focuses on a qualitative approach to the process 
statutes and regulations. Because statutory and regulatory interpretations can vary, input from agencies charged with implementing each statute must be considered, as well as input from affected stakeholders. Other scholars have written extensively about the necessity of identifying and including all stakeholders in a meaningful way to ensure the "objectives" sought to be reached are clearly identified and have obtained some level of approval from stakeholders. ${ }^{170}$

\section{Step 2: Define a set of criteria essential for the attainment of desired objectives}

Simply identifying and articulating the multiple objectives is not enough - decide up front what criteria will be used to measure the attainment of the desired objectives. For example, if improved water quality is one objective, it is necessary to determine how much water quality improvement will be needed to meet this objective. Moreover, protocols must exist for when, where, and how water quality will be sampled and measured. Having clear criteria in place helps ensure that there will be agreement as to when objectives are met. This stage requires significant input from experts, for example water quality scientists, who understand how to measure compliance.

\section{Step 3: Develop a range of alternative solutions}

Developing alternative solutions to solve the problem should involve input from stakeholders, the general public, technical experts, and agency personnel. Suggestion of creative solutions should be encouraged. Unworkable or less-than-optimal solutions can be screened out at later stages. Considerable literature exists on how to involve the public in developing alternative solutions, as well as how to encourage the development of creative solutions by convening processes that encourage creative brainstorming and withhold criticism and judgment until after potential alternative solutions have been identified.

\section{Step 4: Determine which alternative solutions are Pareto optimal}

Once a wide range of alternative solutions has been developed, it is necessary to screen out solutions that are not Pareto optimal, so that the

170. Gregory \& Wellman, supra note 172 , at 52. 
weighting and optimization steps are focused on options that have already been determined to be Pareto optimal. As illustrated above, for complex multi-objective problems, there is no one single solution that simultaneously optimizes every objective. ${ }^{171}$ Therefore, the goal is to find solutions that optimize multiple objectives to the greatest extent possible. In most complex cases, there could be numerous, if not infinite, options that optimize objectives in different ways. The long-recognized approach to generate tradeoff solutions is the use of Pareto optimal solutions. One step of multi-objective optimization, therefore, is filtering out options to leave only those that are Pareto optimal-also referred to as nondominated solutions. ${ }^{172}$ A solution is Pareto optimal if it is not possible to improve any one objective without coincidentally degrading another objective. ${ }^{173}$ In the absence of other preference information (e.g., it is more important to a purchaser to have a safe car than a comfortable car), all Pareto optimal solutions are considered to be equally good solutions. ${ }^{174}$

The use of the set of Pareto optimal solutions, also known as the Pareto frontier, implicitly treats options that are not Pareto optimal as infeasible. ${ }^{175}$ While the literature on MOO calls for the identification of Pareto optimal solutions, it is important to recognize that in complex systems there may be circumstances under which it is valuable to consider options that are not Pareto optimal (e.g., an option that increases the population of one species while causing takes of individuals of another species), but are still legally permissible through a mechanism such as an incidental take authorization. Such options may ultimately be shown to be preferred solutions after the weighting or prioritization factors are applied. ${ }^{176}$ Once Pareto optimal solutions are identified, it is necessary to make tradeoffs or impose subjective preferences of the decision-maker to identify the best solution or solutions.

171. Thiele et al., supra note 167 , at 411 .

172. Jurgen Branke \& Kalyanmoy Deb, Integrating User Preferences into Evolutionary Multi-Objective Optimization, in KNOWLEDGE INCORPORATION IN EVOLUTIONARY COMPUTATION 461-62 (Yaochu Jin ed., 2005).

173. Id.

174. $I d$.

175. See, e.g., Duckstein \& Opricovic, supra notc 167 , at 15.

176. This approach, often referred to as Kaldor-Hicks efficiency, has less stringent criteria than does Pareto optimality in that it allows for solutions that may make somc objectives worse off as compared to the status quo. See generally Oxford Reference, Kaldor-Hicks Efficiency, http:// www.oxfordreference.com/view/10.1093/oi/authority.20110803100028833 (last visited August 20, 2018). 
Step 5: Apply policy-based weighting factors

One challenge of applying this decision-making structure is determining the objectives, and perhaps most importantly, the weighting or prioritization factors that will determine the ultimate outcome. Each of these involves value judgments and policy considerations that go far beyond strict scientific or legal analysis. Policy decisions are not merely a scientific matter, but include value judgements. ${ }^{177}$ Thus, for MOO to be successful, it must integrate values of affected stakeholders. ${ }^{178}$ Stakeholder input in identifying values and priority perspectives is critical to establishing weighting factors to use in the multi-objective optimization process. ${ }^{179}$

Step 6: Use mathematical methods to determine which solutions are closet to ideal for each criterion

Mathematical methodology is beyond the scope of this article and the expertise of this author. However, it should be noted that numerous mathematical methods exist that can assist in identifying which solutions are closest to the ideal for each criterion. For example, Duckstein and Opricovic discuss algorithms that can be used to assist in identifying optimal solutions. They propose one algorithm, Compromise Programming, which finds solutions that are the closest by a measure of distance to the ideal one. ${ }^{180}$

\section{Step 7: Choose the "optimal" solution}

Steps 1-6 should result in the identification of one or more optimal solutions that optimize compliance with the multiple identified weighted objectives as judged against predetermined criteria. At this point, if one clear optimal solution is found, that is the end of the inquiry. If more than one optimal solution is identified, it is ultimately up to the decision-maker to decide among the optimal solutions. Using this step-by-step approach

177. See Holly Doremus \& A. Dan Tarlock, Science, Judgment, and Controversy in Natural Resource Regulation, 26 PUB. LAND \& RESOURCES L. REV. 1, 8-16 (2005) (discussing the differences between scientific and policy judgments).

178. Kiker et al., supra note 166, at 103-104; see also Holly Doremus, Shaping the Future: The Dialectic of Law and Environmental Values, 37 U.C. DAVIS L. REV. 233, 260-261 (2003) (discussing the importance of a robust public discussion of values in environmental law).

179. Id. at 42 .

180. Duckstein \& Opricovic, supra note 167 , at 16. 
should provide a level of transparency and confidence in the system that should provide some level of comfort to affected stakeholder.

\section{The role multi-objective optimization can play in environmental decision-making}

In general, a multi-objective optimization decision-making approach would involve the following steps:

Perhaps nowhere than in environmental decision-making is there a greater need for a structure approach to optimize multiple objectives. Kiker et al. explain that most environmental decisions are "complex and multifaceted and involve many stakeholders with different priorities or objectives - presenting exactly the type of problem that behavioral research has shown humans are poorly equipped to solve unaided." 181 Typically, decision-makers lack a structured approach to address complexity and fall back on intuition or heuristics. ${ }^{182}$ In the absence of a structural framework for decision-making in the face of multiple conflicting objectives, environmental decision makers are forced to use an ad hoc approach.

Using an ad hoc approach, a decision-maker considers factors such as statutory objectives, stakeholder values, scientific data, and economic and other social considerations in deciding how to proceed on a particular policy matter. Even where the decision-maker attempts to gather good information from all stakeholders, there is nothing to guide the decisionmaker on how to take all of the information and competing objectives into account to make the optimal decision. With a structured process to follow, the decision-maker may tend to go with her gut feeling or let her own implicit biases influence the decisions she ultimately makes without even being aware that she is doing so. Equally important, stakeholders and the general public may feel as though decisions are being made in a black box and that their input is being ignored. MOO can provide both the structured approach and the transparency necessary to avoid these perils.

MOO requires decision-making to follow a clear process and, after gathering necessary information, to clearly articulate the objectives to be optimized, the criteria to be used in judging whether or to what extent objectives are being met, and the policy choices that determine the relative

181. Kiker et al., supra note 166 , at 95 .

182. Id. at 95 . 
weight to afford each objective. The process provides opportunity for input at each stage and for the transparency that may provide reassurance to stakeholders and the public. Ad hoc decision-making may not achieve optimal results and does not assure consistency or instill confidence in stakeholders.

The basic concept of attempting to optimize multiple objectives is illustrated by the everyday example of a consumer deciding what type of car to purchase. A consumer with very limited means may have one primary objective - finding the car with the lowest price tag. In this single criterion situation, optimization is simple: the optimal solution is the car with the lowest price, and multi-objective optimization principles are irrelevant. Most decisions, however, are more complex and involve multiple objectives. Even with the decision of which car to purchase, while a good price will certainly be an important objective for most purchasers, a number of other objectives may be equally or even more important. A particular purchaser might have the following objectives: 1 . Price within a certain range; 2 . Fuel efficiency within a certain range; 3 . High safety rating; 4 . Comfortable ride; 5 . Advanced electronic features; and 6. Aesthetics. Some of these objectives, such as cost range and fuel efficiency range may be easily quantifiable. Other objectives such as aesthetics and comfort are not as easily quantified. Moreover, some objectives, perhaps safety in this example, may be more important to the purchaser than others, perhaps advanced electronics. Thus, the question becomes, when faced with a decision with multiple objectives, some quantifiable and some not, some more important to the decision-maker than others, how does the decision-maker make an "optimal" choice? For this example, when deciding between a Honda and a Lexus, where the Honda has a lower price, higher fuel efficiency, and similar safety rating as the Lexus, but is less comfortable and less aesthetically appealing to the purchaser than the Lexus, how can the purchaser make an optimal decision?

Optimizing multiple objective becomes even more challenging where two or more of these objectives are in conflict with each other. For example, in developing an air quality regulation, the objective of attaining maximum reduction in air pollution emissions may be in direct conflict with the objective of minimizing costs to industry. Environmental law has long grappled with the role economic considerations should play vis-a-vis environmental concerns. Virtually every federal environmental law provides direction on how these conflicts are to be resolved. While some 
environmental statutes, such as FIFRA ${ }^{183}$ and the Toxic Substances Control Act, ${ }^{184}$ employ a cost-benefit balances approach, most environmental statutes, including the CWA, ${ }^{185}$ the Clean Air Act, ${ }^{186}$ and the Resource Conservation and Recovery Act ${ }^{187}$ and the Safe Drinking Water Act ${ }^{188}$ direct the Environmental Protection Agency to establish performance standards based on a feasibility approach, where costs are considered but not necessarily determinative. ${ }^{189}$ The greater challenge occurs where one statute's environmental objectives conflict with another statute's related, but different, environmental objectives. These multiobjective problems are more complex and require different approaches than those used to solve simpler optimization problems.

Successful resolution of complex environmental problems is not likely to be achieved without consideration of multiple, at times conflicting, objectives. In addition to conflicting objectives regarding environmental benefit and economic cost, there may be competing environmental benefits or other societal objectives at play. Even where objectives do not directly conflict with each other, objectives may be competing for the same limited economic or natural resources. Optimization in these multi-objective situations necessarily require tradeoffs or compromises among objectives. Environmental agencies have developed tools to analyze proposed alternatives based on costs and benefits. ${ }^{190}$ In fact, since the early 1980 's, Executive Orders have directed federal agencies to engage in cost benefit analysis for all significant regulatory actions. ${ }^{191}$ Environmental objectives may also be in conflict. For example, under some circumstances, protecting habitat for threatened

183. 7 U.S.C. $\S \S 136-136 y$ (2012).

184. 15 U.S.C. $\S \S 2601-2697$ (2012).

185. 33 U.S.C. $\S \S 1251-1387(2012)$.

186. 42 U.S.C. $\$ \S 7401-767 \mathrm{lq}(2012)$.

187. 42 U.S.C. $\S \S 6901-6992 k(2012)$.

188. 42 U.S.C. $\$ \S 300 \mathrm{f}-300 \mathrm{j}-26$ (2012).

189. SIDNEY A. SHAPIRO \& ROBERT L. GLICKSMAN, RISK REgulation at Risk: RESTORING A PRAGMATIC APPROACH 14 (2003).

190. Kiker et al., supra note 166, at 101.

191. The first Executive Order requiring cost-benefit analysis was Exccutive Order 12291 issued by President.Reagan in 1981. Exec. Order No. 12,291, 48 Fed. Reg. 13,193 (Feb. 17, 1981). Since then, every President has required some version of a cost-benefit analysis on regulatory action. See, e.g., Exec. Order No. 12,866, 58 Fed. Reg. 51,735 (Oct. 4, 1993), which was amended by President George W. Bush in Executive Orders 13422 and 13535. See Exec. Order No. 13,563 76 Fed. Reg. 3821, 3823 (Jan. 18, 2011); Exec. Order No. 13771, 82 Fed. Reg. 9,339 (Jan. 30, 2017). 
and endangered species may conflict with efforts to minimize pollution run-off by clearing areas to construct water treatment ponds.

The scholarly literature on environmental decision-making is rich and contains a multitude of decision-making models to assist with choosing between, for example, environmental restoration options against the backdrop of multiple objectives. For years, most environmental agencies relied primarily on approaches in which their decision-making was based on a comparison of a small number of alternatives using one or two factors. For example, decisions based on weighing the costs (typically economic) and benefits (environmental, social, and economic) of a particular environmental regulation. Over time, some agencies have developed more formalized systematic and analytics for considering multiple objectives in their decision-making. Multi-criteria decision analysis has been employed in several environmental policy decisionmaking processes, including environmental remedial technology selection; environmental impact assessments; and natural resources management. Scientific scholars that have 'surveyed the use of multicriteria analysis by environmental agencies have suggested the use of multi-criteria decision-making approaches to specific contexts such as estuary policy initiatives, ${ }^{192}$ everglades restoration, ${ }^{193}$ and water resources development. ${ }^{194}$ Scholars have surveyed the use of multi-criteria decision analysis by federal agencies in environmental decision-making and have found that some individual agencies are incorporating formal decisionmaking tools, such as multi-criteria decision analysis, into their decisionmaking process. ${ }^{195}$ These efforts are modest and do not address problems with multiple statutes, multiple regulatory agencies, and court intervention.

To date, legal scholarship on multi-objective decision-making has been modest at best. Despite the dearth of legal literature on multiobjective decision-making, in recent years legal scholars have grapple with the complexity of environmental problems in distinct but related ways. Two commonly-cited barriers to successful environmental protection are statutory rigidity, with its concomitant regulatory ossification, ${ }^{196}$ and the failure of most environmental laws to address the

192. Gregroy \& Wellman, supra note 167 , at 39 .

193. Convertino et al., supra note 167, at 2922.

194. Duckstein \& Opricovic, supra note 167, at 19.

195. Kiker et al, supra note 166 , at 101 .

196. See generally Thomas O McGarity, Some Thoughts On "Deossifying" The Rulemaking 
complex nature of environmental problems that often involve intricate systems and occur on large scales. Legal scholars have begun to look at ways to employ system-based approaches to resolving environmental problems.

For decades scientists have promoted the idea of "adaptive management," which has been described as "integrat[ing] environmental with economic and social understanding at the very beginning of the process, in a sequence of steps during the design phase and after implementation." 197 Adaptive management shares some characteristics of multi-objective decision-making in that it calls for both an integration of environmental, economic and social concerns and it requires a structured, up-front process that contemplates feedback loops to incorporate new data gleaned from the experience and experimentation. In more recent years, legal scholars have extended the concept of scientific adaptive management to argue for more adaptive forms of governance that adjust to changing circumstances or new information more readily than the difficult to modify statutes, regulations, and policies that permeate modern environmental law. ${ }^{198}$ Scholarly discourse has

Process, 41 DUKE L.J. 1385 (1992) (describing the problem of regulatory ossification); Thomas $\mathrm{O}$ McGarity, The Courts and the Ossification of Rulemaking: A Response to Professor Seidenfeld, 75 TEX. L. REV. 525 (1997) (discussing the role of judicial review in the ossification of agency rulemaking).

197. AdAPtive ENVIRONMENTAL ASSESSMENT AND MANAGEMENT 1 (C.S. Holling ed., John Wilcy \& Sons 1978); Carl Walters, ADAPTIVE MANAGEMENT OF RENEWABLE RESOURCES (Macmillan Publishing Company 1986); Jonathan Z. Cannon, Adaptive Management in Superfund: Thinking like a Contaminated Site, 13 N.Y.U. ENVTL. L.J. 561 (2005); J. B. Ruhl, Taking Adaptive Management Seriously: A Case Study of the Endangered Species Act, 52 U. KAN. L. REV. 1249, 1250 (2004); See, e.g., John H. Davidson \& Thomas Earl Geu, The Missouri River and Adaptive Management: Protecting Ecological Function and Legal Process, 80 NEB. L. REV. 816 (2001); Alfred R. Light, Tales of the Tamiami Trail: Implementing Adaptive Management in Everglades Restoration, 22 J. LAND USE \& ENTL. L. 59 (2006); Bryan G. Norton, The Rebirth of Environmentalism as Pragmatic, Adaptive Management, 24 VA. ENVTL. L.J. 353 (2005); J.B. Ruhl, Regulation by Adaptive Management - Is It Possible?, 7 MiNN. J.L. SCI. \& TECH. 21 (2005); Julic Thrower, Adaptive Management and NEPA: How a Nonequilibium View of Ecosystems Mandates Flexible Regulation, 33 ECOLOGY L.Q. 871 (2006); Joy B. Zedlcr, Adaptive Management of Coastal Ecosystems Designed to Support Endangered Species, 24 ECOLOGY L.Q. 735 (1997).

198. Barbara A. Cosens, Lance Gunderson \& Brain C. Chaffin, Introduction to the Special Feature Practicing Panarchy: Assessing Legal Flexibility, Ecological Resilience, and Adaptive Governance in Regional Water Systems Experiencing Rapid Environmental Change, 23 ECOLOGY \& SoC'Y, 2018, at Article 4; Barbara A. Cosens et al., The Role of Law in Adaptive Governance, 22 ECOLOGY \& SOC'Y, 2017, at Article 30; Convertino et al., supra note 167; Robin K. Craig et al., Balancing Stability and Flexibility in Adaptive Governance: An Analysis of Tools Available in U.S. Environmental Law, 22 ECOLOGY \& SOC'Y 3 (2017); Daniel A. DeCaro et al., Legal and Institutional Foundations of Adaptive Environmental Governance, 22 ECOLOGY \& SOC'Y, 2017, at Article 32; Daniel A. DeCaro et al., Understanding and Applying Principles of Social Cognition 
centered on the concept of finding ways for the law to be less rigid and more adaptive to better take into account the dynamic nature of ecosystems, changing circumstances, such as from climate change, or new understandings of ecological systems. Adaptive governance addresses shareholder identification of objectives, decision-making, and actions to meet those objectives. ${ }^{199}$ Inclusion of all stakeholders is critical to achieving a governance system that can address economic, environmental, social, and political shifts. ${ }^{200}$ Proponents of adaptive governances maintain that current environmental governance structures tend to be static; without introducing more flexibility into such systems, they will not be able to adapt to changes in social-economic systems. ${ }^{201}$ Rigid environmental laws can create roadblocks to the types of changes necessary to address quickly-changing circumstances, such as with climate changes. ${ }^{202} \mathrm{MOO}$ can be used as a tool of adaptive management. MOO incorporates many principles of adaptive governance including stakeholder input to identify priorities and flexibility to overcome artificial barriers created by rigid adherence to the status quo.

Related to the concept of adaptive management and adaptive governance is the concept of resilience. Ecological resilience has been described as a measure of the amount of change or disruption that an ecological system can withstand without crossing a threshold that causes the system to flip to a different state. ${ }^{203}$ In many cases, human perturbations such as through pollutant loading or habitat destruction cause an ecosystem to cross that threshold and be transformed into a less desirable state: A common example is nutrient loading into a lake that

and Decision Making in Adaptive Environmental Governance, 22 ECOLOGY \& SOC'Y, 2017 at ARTICLE 33; Hannah Gosnell et al., Transforming (Perceived) Rigidity In Environmental Law Through Adaptive Governance: $A$ Case Of Endangered Species Act Implementation, 22 ECOLOGY \& SOC'Y, 2017, at Article 42; Lance H. Gunderson et al., Escaping the Rigidity Trap: Governance and Adaptive Capacity to Climate Change in the Everglades Social Ecological System, 51 IDAHO L. REV. 127 (2014).

199. Craig et al., supra note 198.

200. DeCaro et al., Legal and Institutional Foundations of Adaptive Environmental Governance, supra note 198.

201. Id. at 3-6.

202. Cosens et al., supra note 198.

203. ADAPTIVE ENVIRONMENTAL ASSESSMENT AND MANAGEMENT, supra note 197; Garry Peterson, Contagious Disturbance and Ecological Resilience, 216 (1999) (unpublished Ph.D. dissertation, University of Florida) (contrasting ecological resilience with engineering resilience, which is defined as "the rate at which a system returns to a single steady or cyclic statc following a perturbation"). 
causes the lake to become eutrophic and become algae-clogged. ${ }^{204}$ As with adaptive management, legal scholars have extrapolated the concept of resilience and applied it to legal and governance structures. ${ }^{205}$ These approaches often take the form of looking at the overall resilience of a particular ecosystem as opposed to merely focusing on one ecosystem attribute, such as a particular species. As with adaptive governance, MOO can serve as a tool of governance resilience in that it inherently does not focus on single ecosystem attribute, but instead looks system-wide to consider how best to optimize multiple objectives. Although legal scholarship on adaptive governance and resilience has made significant contributions to the field of environmental management, restoration, and regulation and inherently encompasses some aspects of multi-criteria decision-making, it has not squarely addressed a process for making decisions when multiple statutory objectives or requirements are discordant. The proposal to adopt MOO methodology contributes and builds on existing scholarly discourse regarding adaptive and resilient governance by providing a pragmatic and systematic approach for . resolving these discordances.

\section{Using Multi-ObJective Optimization: A Fictional Example}

As can be seen from the examples above, there are many real-world situations where discordant environmental laws containing conflicting objectives have created significant challenges in accomplishing environmental protection or restoration goals. For purposes of this article, a fictional case study demonstrates how multiple objective optimization might be used to resolve these types of conflicts. ${ }^{206}$ The case study used is loosely based on the Everglades example; however, the case study facts are different from the facts of the Everglades restoration project and the case study is greatly simplified for the purposes of illustration. It is not

204. Craig R. Allen et al., Quantifying Uncertainty and Trade-Offs in Resilience Assessments, 23 ECOLOGY \& SOC'Y, 2018, at Article 3, 1; Stumbling Toward Success: A Story of Legal Adaptation and Ecological Resilience, 87 NEBRASKA LAW REVIEW 950 (2009).

205. Allen et al., supra note 204; Craig Anthony (Tony) Arnold et al., Cross-Interdisciplinary Insights into Adaptive Governance and Resilience, 22 ECOLOGY \& SOC'Y, 2017, at Article 14; Cosens, supra note 198.

206. This fictional scenario is looscly based on a large-scale restoration project which shares some characteristics similar to those in the Everglades. However, the scenario is fictional and oversimplificd and is intended merely to demonstrate the process of multi-objective optimization. The actual issues related to Everglades restoration and other large-scale restoration projects are far more complex and nuanced. 
intended to provide any specific legal advice or guidance on the complex challenges facing Everglades restoration.

In this fictional case study, an ecosystem restoration project is proposed in an area that has historically been altered by human activity. Parts of the system have been drained and water has been diverted from the system for other uses, leaving historic wetlands dry. To restore the ecosystem, it is necessary to reestablish historic hydrology by both reversing drainage and restoring water flow to the area. Several environmental laws are invoked in the restoration project. With regard to the specific circumstances of this project, there are conflicting objectives among the various environmental statutes. To restore water flow to the system, it is necessary to add water from agricultural and urban areas that are now contaminated with various human contaminants. The CWA prohibits discharges of the contaminated water to the natural wetland areas unless EPA-approved water quality standards are met. Currently the water quality standards cannot be met and efforts to improve water quality to the point of compliance with strict water quality standards may take large amounts of money and decades to accomplish.

The wetland area to be restored is historic habitat for a species of mammal, which will be referred to as species "A." This species requires a minimal depth of water for a large portion of the year. The drainage and other alterations that have occurred to the system have caused drying and deterioration of the wetlands to the point that they are no longer good habitat for species A. Due to widespread wetland destruction and degradation throughout the geographic area, species A's population has plummeted, and it has been listed as an endangered species under the ESA. The second species, a bird species, which will be referred to as species " $B$," is not threatened or endangered. This species requires habitat that is significantly drier than the ideal habitat for species A. Species B currently occurs in significant numbers within the habitat to be restored. However, due to its historically wet condition, this area to be restored was not within the historic range of species $\mathrm{B}$. This species is not currently listed under the ESA but is protected by the MBTA. The wetland was not within the historic range of species $\mathrm{B}$, because historically it was too wet to support the habitat needs for the species. Over the past decades during which the area was drained by human activity, bird species B has established nesting grounds within the area to be restored. This fictional case study sets up a conflict between compliance with the CWA, the ESA, and the MBTA. If sufficient water is not restored to the habitat, species A, a listed species, may go extinct. To restore water to the habitat, 
however, is not currently possible without violating the CWA requirement that EPA-approved water quality standards be met. If water is restored to the system, species B could be harmed to the extent that, not only might there be violations of the MBTA, but its population numbers may decline to the point where it qualifies for listing under the ESA. Under any scenario, a possible violation of at least one environmental statute will occur.

If there were no flexibility or opportunities for creative interpretation or other discretionary action within the statutes at issue, there would be a stalemate. Under such a stalemate, the status quo might be maintained, in which case the habitat would not be restored and Species A, a listed species, would suffer and could become extinct. This outcome might occur due to bureaucratic inertia and unwillingness to deal with the conflict or because an environmental group brings a citizen's suit under the CWA. The mere risk of a lawsuit under the CWA or MBTA may be sufficient to deter or delay restoration efforts. Another possible outcome is that the agencies in charge of restoration could decide to move forward with the restoration without full compliance with the CWA, due to the imminent threat to species A and the necessity of restoring hydrology to the wetland area. Without any statutory flexibility or agency discretion, this problem appears to be intractable.

Before conducting a MOO analysis, a screening step occurs to determine if there is statutory flexibility or if statutory requirements are absolute and there is no way to craft a solution that could meet objectives of the three statues without violating the law. The question then becomes which solution is optimal.

\section{Step 1: Define and identify multiple desired objectives}

If we assume that some flexibility and discretion exist that allow solutions that do not violate the law, the first step is to identify the objectives based on the three statutes. In this scenario the objectives are: (1) Restore the degraded ecosystem; (2) Meet water quality standards; (3) Protect species A and its habitat; and (4) Protect species B and its habitat. Economic feasibility could be an additional objective.

\section{Step 2: Define a set of criteria essential for the attainment of desired objectives}

The next step involves defining a set of criteria necessary to measure whether desired objectives are being met. In this fictional scenario, these 
criteria could include: (1)_Specified hydrologic conditions and ecological community structure that represent a restored ecosystem; (2) A specific water quality concentration that represents compliance with a water quality standard promulgated under the CWA; (3) Specified population of Species A; (4) Specified population of Species B; and (5) Costs within a specified acceptable range.

\section{Step 3: Develop a range of alternative solutions}

A range of alternative solutions designed to address the issues could include: (1) No action; (2) Restore hydrology before water quality improvements have been made; (3) Delay hydrologic restoration until after water quality improvements have been made; (4) Focus resources on improving water quality and restoring hydrology in one-half of the area, leaving the other half in the status quo; and (5) Restore hydrology in limited geographic locations as water quality in those areas is improved and continue to expand areas of restored hydrology as more water quality improvements are made. There are a potentially infinite number of other solutions that could be identified.

\section{Step 4: Determine which alternative solutions are pareto optimal}

The fourth step would be to identify a range of Pareto optimal solutions. Solutions that would result in a violation of an absolute statutory requirement for which there is no statutory flexibility mechanism or agency discretion permitted would have been screened out from consideration at Step 1 and would not make it to the list of Pareto optimal solutions. The various alternative solutions identified in Step 3 will be filtered out at this point. For example, Option 1, the no action option, would not be Pareto optimal because it will result in increased harm to species A. Also, Option 2 of restoring hydrology prior to water quality improvements most likely would not be Pareto optimal because it will further degrade the ecosystem though water quality impacts and will destroy habitat for species $B$. 


\begin{tabular}{|l|l|l|l|}
\hline Objectives & Option 1 & Option 2 & Option 3 \\
\hline $\begin{array}{l}\text { Restore Ecosystem } \\
\text { Hydrology }\end{array}$ & 0 & ++ & + \\
\hline Water Quality & ++++ & ++ & ++ \\
\hline Species A & 0 & ++ & ++ \\
\hline Species B & ++++ & ++ & ++ \\
\hline Costs & + & ++ & ++ \\
\hline
\end{tabular}

Figure 1. Example of Identifying Pareto Optimal Options

Figure 1 illustrates a simplified set of potential solutions. Multiobjective optimization can provide a framework for choosing among these alternatives. For purposes of this exercise, it is assumed that each option in Figure 1 is Pareto optimal in that it would not be possible to improve one objective further without degrading another. In this situation, there could be a wide range of potential solutions ranging from maintaining the status quo to full ecosystem restoration. For each solution or option $(1,2$, and 3$)$, the objectives of restoring the ecosystem hydrology, improving water quality, protecting listed species A, protecting MBTA-protected species $\mathrm{B}$, and minimizing costs are evaluated. The number of plus symbols indicates the extent to which a particular option improves an objective. Zeros indicate no change from status quo for the particular objective. As can be seen from Figure 1, each of the listed options benefits some objectives to varying extents. Counting up plus symbols does not necessarily demonstrate which of the options represents the best solution because stakeholders' values may attribute distinct weights to different objectives.

\section{Step 5: Apply policy-based weighting factors}

To accomplish this, it is necessary to include value and policy choices, which can be applied by using weighting factors. Value and policy-based weighting factors would be established in advance of decision-making based on decision-maker policy preferences and meaningful input from the full range of stakeholder communities. Factors to be considered in weighting could include, for example, the following:

1. A preference for protecting species that are capable of recovery and are not "lost causes";

2. A preference for protecting species that do not have significant alternative habitat available; 
3. A preference for protecting the most imperiled species;

4. A preference for protecting species that existed in the area prior to human alteration;

5. A preference for avoiding environmental harms that are irreversible (e.g., species extinction) or values that once destroyed are irreversible or only reversible over a very long time (e.g., water resources eutrophication);

6. A preference for options that have ecosystem-wide benefits rather than benefiting individual species or resources;

7. A preference for restoring habitat to pre-anthropogenic alteration conditions;

8. A preference for options for which there are mitigation or offset options readily available; and

9. A preference for options that are unlikely to be successfully challenged in court due to clearly applicable statutory flexibility mechanisms.

It is important that the weighting factors be established early in the process and are not used as post hoc rationalizations for decisions that are made. If the preferences described above are inserted as weighting factors, a preferred solution may emerge.

\section{Final Step: Choose the "optimal" solution 207}

The final step in the Multi-Objective Optimization process is to determine which option, or options, representing a set of trade-offs, is the optimal solution.

\section{CONCLUSION}

This Article suggests Multi-Objective Optimization as a methodology to harmonize discordant statutory objectives. Section II illustrates, by means of several examples, the ways in which environmental statutory objectives and processes come into conflict. Although most states allow for at least some flexibility in their implementation, in the absence of a structured framework for multi-objective decision-making, policymakers are left to make ad hoc decisions. Ad hoc decision-making is not ideal

207. Because it is beyond the scope off this article and beyond the expertise of this author, Step 6, using mathematical methods to determine which solutions are closest to ideal for each criterion, is not included. 
for optimizing multiple objectives or assigning priority to those objectives that science, policy or stakeholder values deems most important. Further, ad hoc decision-making often occurs in a black box where it lacks the transparency necessary to gain stakeholder confidence in the decisionmaking process. The lack of a systematized methodology also increases the risk that ad hoc decisions will be the arbitrary whim of the decisionmaker and will not have coherence with other similar decisions. Finally, the lack of a decision-making framework to resolve discordancy and optimize multiple competing objectives can lead to paralysis. Decisionmakers may be reluctant to decide issues because they are not sure how to proceed in the face of conflicting objectives or for fear of running afoul of one law by complying with another conflicting law. An example of this is that the EPA failed for decades to engage in ESA consultation on pesticide regulatory decisions because of the challenges of harmonizing FIFRA and ESA objectives and processes.

Moreover, regulatory paralysis is not simply a lack of decisionmaking. By failing to decide, an agency fails to act, which in some circumstances prevents or delays important environmental protection actions or leads to environmental degradation occurring during the time the agency fails to take action. For example, if the stringent water quality standards required for water entering the Everglades Protection Area lead to further delay in restoring the hydrology of the system, the system will further degrade. Areas of the Everglades starved for water may undergo peat collapse or subsidence and species requiring wetter conditions may suffer.

The mechanics of the MOO approach in Section IV demonstrate the steps of the MOO process and the ways in which statutory objectives are incorporated into the process. It further demonstrates the way that science, economics, and stakeholder values can shape the process and identify and apply priorities through the development and use of "weighting factors." This Article represents a first step in advancing the application of MOO to discordant environmental law objectives. In the future, it may to possible to develop quantitative methodologies that could enhance the process.

Multi-objective optimization holds the potential of reconciling discordant environmental statutory objectives and processes by systematically guiding agencies through a decision-making process of identifying and choosing among options. By establishing a transparent consistent process and acquiring agency buy-in to the process, agencies will have more security that they are proceeding in the proper fashion 
without fear of alienating other agencies or running afoul of laws implemented by other agencies. Stakeholders will have a clear opportunity and point of entry for input into determine the "weighting factors." Decision-making will be accomplished in a transparent manner that can help stakeholders to better understand agencies' choices and may help to build trust between stakeholders and policy-makers.

\section{Glossary of Acronyms and Abbreviations}

$\begin{array}{ll}\text { BiOp } & \text { Biological Opinion } \\ \text { CWA } & \text { Clean Water Act } \\ \text { EPA } & \text { Environmental Protection Agency } \\ \text { ESA } & \text { Endangered Species Act } \\ \text { FIFRA } & \text { Federal Insecticide, Fungicide and Rodenticide Act } \\ \text { FWS } & \text { Fish and Wildife Service } \\ \text { MBTA } & \text { Migratory Bird Treaty Act } \\ \text { MOO } & \text { Multi-Objective Optimization } \\ \text { NFMA } & \text { National Forest Management Act } \\ \text { NMFS } & \text { National Marine Fisheries Service } \\ \text { NPDES } & \text { National Pollutant Discharge Elimination System } \\ \text { NRC } & \text { National Research Council } \\ \text { STA } & \text { Stormwater Treatment Act } \\ \text { WQBEL } & \text { Water Quality Based Effluent Limitation } \\ \text { WQS } & \text { Water Quality Standard }\end{array}$


